Max-Planck-Institut für demografische Forschung

Max Planck Institute for Demographic Research

Konrad-Zuse-Strasse 1 - D-18057 Rostock - GERMANY

Tel +49 (0) 3812081 - 0; Fax +49 (0) 3812081 - 202;

http://www.demogr.mpg.de

MPIDR WORKING PAPER WP 2011-013

AUGUST 2011

\title{
The fertility behaviour of East to West \\ German migrants
}

Anja Vatterrott (vatterrott@demogr.mpg.de)

This working paper has been approved for release by: Michaela Kreyenfeld (kreyenfeld@demogr.mpg.de), Acting Deputy Head of the Laboratory of Economic and Social Demography.

(C) Copyright is held by the authors.

Working papers of the Max Planck Institute for Demographic Research receive only limited review. Views or opinions expressed in working papers are attributable to the authors and do not necessarily reflect those of the Institute. 


\title{
The fertility behaviour of East to West German migrants
}

\author{
Anja Vatterrott
}

\begin{abstract}
In the twenty years since the reunification of Germany, we have seen a convergence of total fertility rates in the eastern and western parts of the country, but differences remain in the timing, number and spacing of births. Our aim in this paper is to better understand the persistence of these differences by studying the fertility behaviour of migrants from the East to the West. Millions of people have followed this migration path in recent decades, mainly in response to the unfavourable economic conditions in the East. We use data from the German Socio-Economic Panel of the years 1990 to 2009. Using event history modelling, we analyse whether the first and second birth behaviours of female East-West German migrants resemble the patterns of one of the non-mobile populations in the eastern or western parts of the country. We find that migrants' first and second birth risks lie in between those of non-mobile eastern and western Germans. Socio-economic characteristics, value orientations and partners' characteristics are employed as explanatory variables, but do not fully account for the differences between the three groups. We investigate whether the special behavioural patterns of migrants can be explained by the fact that they are a selected group, but do not find support for this hypothesis.
\end{abstract}

Keywords: internal migration, East Germany, fertility 


\section{Introduction}

Since German reunification, millions of people have migrated from the eastern to the western states of Germany. The major push factors that explain the migration flows are unemployment, the disappearance of industries and economic deprivation (Hunt 2000). More recent research shows that young women with qualifications are the most likely group to migrate from eastern to western Germany ${ }^{1}$, which means that the eastern states are "losing births" to western Germany (Kröhnert and Klingholz 2007:72, Mai and Scharein 2009:88). But even though we know a fair amount about what prompts eastern Germans to migrate, we know very little about how these migrants behave after they have settled in western Germany. This particularly pertains to their family behaviour.

In this study, we focus on the first and second birth behaviours of East-West migrants. Studies of German fertility dynamics have shown remarkable and persisting differences between eastern and western Germany. Eastern Germans are still younger at first birth than their western German counterparts (Kreyenfeld et al.2010). They are less likely to be married when they have a child (Kreyenfeld and Konietzka 2008). Furthermore, they seem to have lower second birth rates, and are more likely to express a preference for having one child only when they are queried about the number of children they would like to have (Dorbritz and Ruckdeschel 2009). A portion of these East-West differences could be explained by the different constraints in the two parts of Germany. Although the Unification Treaty ${ }^{2}$ prescribed that the eastern German legal and political framework was to be abolished in favour of the

\footnotetext{
${ }^{1}$ We use eastern/East and western/West Germany interchangeably for stylistic variation, referring to the federal states corresponding to the area of the former German Democratic Republic (GDR) and Federal Republic of Germany (FRG) before unification in 1990.

${ }^{2} \mathrm{http}: / / \mathrm{www}$. gesetze-im-internet.de/bundesrecht/einigvtr/gesamt.pdf
} 
framework of the western states, some East German features were retained after reunification. In particular, day care coverage is still much higher in the East than in the West (Kreyenfeld and Krapf 2010). However, labour market conditions are much worse in the eastern than in the western states.

By focusing on the fertility behaviour of East to West migrants, we hope to better understand the determinants of fertility behaviour in Germany. We specifically want to tease out to what extent cultural and institutional factors influence demographic behaviour. East to West German migrants are an especially suitable study population for this purpose. Existing studies on the demographic behaviour of international and internal migrants seek to separate out the cultural and the institutional factors that determine fertility (see e.g. Andersson and Scott 2007). However, a drawback of these studies is that the institutional, economic and cultural characteristics of the host country often differ radically from those of the country of origin. Other studies centre on the connection between internal - mostly rural-urban - migration and family development. The advantage of studying East to West German migrants is that these migrants have similar cultural backgrounds. Although East and West Germany differ in many respects, they are still comparable on more levels than distinct nation states because of a shared history and language. East-West German migrants hold the citizenship of the receiving region, and therefore have immediate access to the West German labour market, unlike the labour migrants of the 1970s (Seifert 1997). Moreover, an analysis of East-West German migrants can provide insights that differ from those of studies of migration between rural and urban areas, and from the findings of studies of migrants between regions of a country that has not undergone the historic experiment of separation that Germany has. In contrast to most studies of 
migration, the great advantage of our study is that we can examine all three relevant groups: the population at origin, the migrants and the population at destination.

We assume that even younger eastern Germans are socialised differently from their western German counterparts, especially by parents, older family members, teachers and other influential social agents who have experienced the socialist system. This socialisation is reflected in their attitudes, and, subsequently, in their (demographic) behaviour (Mayer and Schulze 2009). The question remains, however, of whether the persistence of differences in attitudes in eastern and western Germany is rooted in a delayed adaptation to western Germany - i.e. in a 'resistance to modernisation' (Alheit 2005) - or in the development of an altogether new 'postmodern orientation' (Bernardi et al. 2008). The emergence of postmodern values in eastern Germany includes the possibility of a reversed adaptation of the western German to the eastern German family patterns in the future (Kreyenfeld and Konietzka 2008).

The paper is structured as follows. The following section (Part 2) develops the theoretical framework. Part 3 summarises prior research on migration and fertility behavior in Germany. The data from the German Socio-Economic Panel (GSOEP) is described in Part 4, while Part 5 contains the empirical investigation. We apply event history techniques, with the regional variation modelled through a time-varying covariate that picks up the place of residence. Thus, it is possible for a respondent to change their status from eastern German to East-West German migrant in the span of observation if they change their place of residence. First, hazard rates are graphed for the transition to a first birth by age and to a second birth by duration since the time of the first birth for eastern and western Germans and for East-West migrants to get an overview of the fertility behaviours of these groups. In a second step, multivariate models are applied to control for additional characteristics. Two main types of 
confounding factors are considered: socio-economic characteristics and orientations toward family and employment. The models will shed light on the question of whether differences in the fertility behaviours of East-German migrants and the nonmobiles can be attributed to the peculiarities in the composition of the migrant population. We estimate here individual models for all respondents, as well as models for respondents in a cohabiting relationship, which enable us to account for partner characteristics. The last section (Part 6) concludes.

\section{Theoretical Framework}

Drawing from the multi-dimensional aspect of the life course approach, we see the life course as a product that evolves from decisions that are made in the residential, employment, partnership and family domains (Huinink and Konietzka 2007: 43f.). Making decisions in one life domain influences the set of possible behaviours in other domains (Willekens 1991). Thus, migration decisions can influence decision-making or behavioural options in the reproduction sphere. Furthermore, our work contributes to the debates about the importance of institutional vs. cultural factors and values vs. economic factors, and about the significance of socialisation. We want to find out whether migrants, when confronted with an institutional setting incompatible with their cultural understanding of the factors that should influence the decision to have a first or additional child, still cling to their learned perceptions, or adapt to the new institutional conditions.

First-generation migrants are generally assumed to act according to five partly competing hypotheses. If the norms and values experienced during childhood and adolescence are the chief determinants of migrants' behaviour, migration or the conditions in the host society are not going to change it (socialisation hypothesis). 
Migrants could be a selected group with preferences that resemble those of the population at their destination. If this were the case, then they would not behave like the population in their area of origin, and would instead behave more like the population at destination (selectivity hypothesis). For some groups of migrants, and especially regarding women and family formation, the move, the formation or institutionalisation of a partnership and the decision to have a first child could be closely connected (interrelation of events hypothesis). In this case, a birth would occur close to the time of migration. But migration could also disrupt careers in other life domains and delay demographic events in the period immediately following migration, because migrants have to get accustomed to their new place of residence (disruption hypothesis). Finally, migrants might adapt to the behaviour of the population in the host society over time if they react to their surroundings in the same way (adaptation hypothesis). ${ }^{3}$ The adaptation hypothesis assumes that migrants adopt the behavioural pattern in the country of destination. An important mechanism by which such an adaptation may occur is through the attitudes and behaviour of the partner, if the partner comes from the country of destination.

Milewski (2009) has found such an effect for second birth risks of international migrants in Germany. However, she stated that this effect could also be attributed to the possibility that women who choose a partner from a different country constitute a special group. The adaptation-enhancing effect of having a German partner has also been documented for the completed fertility of some groups of international migrants to Germany, with the exclusion of Polish women. For them, having a German partner had a fertility-enhancing effect, which the authors attributed to the interrelatedness of migration and family formation for this group (Schmid and Kohls 2009).

\footnotetext{
${ }^{3}$ For more detailed discussions of these hypotheses, see e.g. Kulu and Milewski 2007, Mussino and van Raalte 2008, Milewski 2009, Schmid and Kohls 2009.
} 
Migration and union formation are often related (for internal migration, see e.g. Mulder 1993, Kulu 2004 and 2005). For international migrants in West Germany, migration, marriage and the first birth are strongly interrelated. The transition to a first pregnancy is greatly increased in the first year after migration, and declines over time as migrants adapt to the behaviour at the destination (Milewski 2007). The same author did not find any disruption effect on fertility for international migrants to Germany (Milewski 2009: 133). Evidence for the adaptation of fertility among immigrants was also found by Andersson and Scott (2007) for Sweden, and by Schmid and Kohls (2009) for Germany, although the latter also found evidence for selection and interrelation of events for Polish migrants. International migrants to Europe adapt over time to the fertility behaviour at destination, but retain differences based on their origin (Sobotka 2008). Mussino and van Raalte (2008) found that migrants, regardless of the host country, act as a distinct group. However, in most contexts, the effects of adaptation and disruption cannot be distinguished because migrants come from countries with higher levels of fertility than the countries of destination. Okun and Kagya (2011) were able to test the effects of adaptation and disruption against each other when studying the fertility of immigrants from the Former Soviet Union to Israel. The effects of disruption prevailed in this context.

The behaviour of internal migrants in Germany should differ considerably from that of international migrants since the majority of relocations are not marriage-related, but are instead for employment reasons (Schneider 2008). For internal migrants, both adaptation and selection effects on fertility have been documented (Kulu 2004, White et al. 1995). Moreover, repeated internal migration is correlated with raised separation risks that could have mediated effects on fertility (Boyle et al. 2008). 


\section{Research Hypotheses}

In this article, we hypothesise that East-West German migrants will behave according to the socialisation, adaptation or selection hypothesis. The socialisation hypothesis in the given context would mean that East to West German migrants behave like eastern Germans in eastern Germany. Under the adaptation hypothesis, however, they would, over time, behave increasingly like western Germans in western Germany. For the selection hypothesis to be true, the migrants would have to be a special group of eastern Germans who decided to migrate to western Germany because of their personal preferences, and they would display fertility behaviour that differs from that of the overall population in eastern Germany, and resembles that of western Germans. Since fertility decisions are usually made in the context of a couple, we assume that the partner's origin can play a role in the adaptation process, as well. East-West German migrants with a partner from the West would display behaviour that is more similar to that of western German women because they are influenced by their partners' preferences.

\section{Institutional Background}

\subsection{Family Dynamics in East and West Germany}

After reunification, period fertility rapidly declined in eastern Germany in the course of a 'demographic shock', falling to an historical low of 0.77 in 1994. By 2008, however, eastern and western German period fertility rates had converged to a level of 1.4 children per woman. Fertility declines in the former socialist states have been attributed to the economic and social crises surrounding the transition to capitalism, and the diffusion of the norms, values and attitudes of the western capitalist states. 
The 'root cause' of both is the replacement of the socialist regimes with capitalist institutions (Frejka 2008). Despite this overall harmonisation in period fertility indicators, behavioural patterns in the two parts of Germany still differ. First, there are differences in the age at childbirth, with eastern German women being about a year younger at first birth than their counterparts in the West (Kreyenfeld et al. 2010). Although the first child is born earlier, the spacing between the first and second child is wider in the East than in the West (Kreyenfeld 2003). There are also huge differences in the share of nonmarital births in East and West Germany, which had already existed before unification, but increased even more after 1990. In the East, 61 per cent of children were born outside of marriage in 2009, compared with only 26 per cent in the West (Klüsener and Goldstein 2009, Klüsener and Kreyenfeld 2009, Kreyenfeld and Konietzka 2010). The transition to first marriage occurs later or not at all in the East, resulting in a higher proportion of never-married people than in the West, in part because, in contrast to the West, family formation and marriage are only loosely connected in the East. Childless and two-child families are less prevalent in the East, while western Germans are polarised between childlessness and having more than one child.

The employment patterns of eastern and western German women, which are related to the differences in fertility behaviour, also differ radically. Eastern German women are more likely to contribute equally to the family income or be the sole breadwinner than western German women (Brehmer et al. 2010). Despite a slight convergence in maternal employment rates, in 2002 three times more mothers in eastern Germany were employed full-time than in western Germany, where mothers are typically employed part-time or marginally (Kreyenfeld and Geisler 2006). Maternal employment in the East is facilitated by a high coverage of institutional child care, 
while coverage of public day care has remained low in the West, especially for children under three years old and school-age children. Furthermore, children in the West who are in public day care spend fewer hours per day in care than children in the East (Kreyenfeld and Geisler 2006, Kreyenfeld and Konietzka 2008, Kreyenfeld and Krapf 2010). Due to the restricted availability of day care, women in the West are under greater pressure to choose between employment and motherhood as two separate life goals. In contrast to this sequential approach, employment and family are seen as compatible and parallel careers in the East (Bernardi et al. 2008).

The differences in employment behaviours are mirrored by differences in attitudes towards children, employment and family life. Childlessness and the overall decline in birth rates are assessed more negatively in eastern than in western Germany, while marriage is seen as a prerequisite to family formation by only one-quarter of young adults in the East, compared to over one-third in the West (Dorbritz and Ruckdeschel 2009: 268). Moreover, single parents are more accepted by eastern Germans. Regarding employment, the ideal of western German women is to withdraw from the labour force or to work part-time while raising (small) children, while the majority of eastern German women want to combine full-time employment and motherhood (ibd: 279).

\subsection{Characteristics of East to West Migrations}

Migration from the GDR to the FRG was heavily restricted, but was stable at a low level following the construction of the Berlin Wall in 1961 (Geißler 2004). After 1989, East-West migration in Germany occurred in two waves (see Figure 1). The first wave was around the time of reunification, or 1989-1990, when future migration opportunities and political developments were unclear, and almost 600,000 or 3.7 per cent of the East German population migrated west. Immediately after German 
reunification, over one-third of East Germans said they could imagine moving to the West. Those who realised such a move were disproportionally young and skilled, and faced unfavourable employment situations: being laid off, unemployed or in temporary working contracts (Büchel and Schwarze 1994, Hunt 2000). After 1997, out-migration from the East to the West, especially of the young and educated, increased again and peaked in 2001. Between 1990 and 2006, 2.8 million people migrated from the East to the West, with a negative net migration of 1.3 million for eastern Germany. ${ }^{4}$ The second wave of migration coincided with a favourable labour market situation in the West, which contrasted with economic stagnation in the East (Heiland 2004). The onset of this migration wave might also be attributable to a declining belief in further East-West convergence in life style and employment opportunities (Fuchs-Schündeln and Schündeln 2009). Qualified young East Germans were at the forefront of the recent migration wave (Brück and Peters 2009: 13, Büchel and Schwarze 1994, Hunt 2000, Brücker and Trübswetter 2004, Gernandt and Pfeiffer 2008).

\section{[FIGURE 1 ABOUT HERE]}

Economic conditions have remained an important push factor for East to West migration. This corresponds to the subjective motivations for migration. The most frequently mentioned reasons for migration are employment and partnership prospects. Heiland (2004) found, for example, that the economically strongest regions in the West - and not those nearest to the former inner-German border - experience the strongest in-migration. This supports the importance of employment options for the decision to migrate. Migration rates are positively associated with the population size of the area of destination and the destination being a city-region, and are

\footnotetext{
${ }^{4}$ For a detailed description of migration streams from the eastern German to the western German states between 1989 and 2002, see Heiland (2004); for a description of employment-based outflow mobility by regions from 1992 to 2001,see Windzio (2008).
} 
negatively associated with the proximity to the destination (see also Windzio 2008). Brücker and Trübswetter (2004) argued that differences in wages and overall employment opportunities were the main reasons behind East-West migration in Germany after reunification. For childless young adults, the perception that there are better career opportunities elsewhere is, in addition to starting tertiary education, the strongest predictor of the decision to change their place of residence (Kley 2010). Kröhnert (2009) and Zaiceva (2010), on the other hand, argued that women moved primarily for partnership reasons, e.g. to find or move in with a partner, while men seldom migrate as singles. Kröhnert (2009) speculated that a shortage of equally qualified partners for highly skilled women in the East, along with insufficient demand for those women on the labour market, could be the reasons behind these differences in behavioural patterns. By contrast, Stauder (2010) found that there are more men than women with a high school degree on the partner market in most of East Germany. Consequentially, men with a medium or low school degree would face difficulties in finding a partner in eastern Germany.

It is also important to consider that a large fraction of the migrants have not permanently settled in western Germany, but have returned to eastern Germany. According to estimates based on the GSOEP, about 20 per cent of East-West migrants returned to the East within four years (Fuchs-Schündeln and Schündeln 2009). Singles and older people were more likely to migrate temporarily, probably because the cost of adjusting to a new place of residence is lower for them than for people with families, who face challenges like finding employment for the spouse and schooling for the children. ${ }^{5}$

\footnotetext{
${ }^{5}$ An analysis of migrations occurring during our time of observation with data from the GSOEP verifies that women, young people, people who are single or in a non-cohabiting relationship, individuals without children and people with a high school degree have higher risks of migration; and migration was most prevalent in the periods 1990-1994 and 2000-2004 (see Appendix A).
} 


\subsection{Findings on the Demographic Behaviour of Migrants}

While quite extensive literature exists on the decision to move from East to West Germany - including on the determinants and the labour market and economic outcomes of these transitions - the demographic behaviour of those migrants after they changed their place of residence has scarcely been investigated. One study, undertaken by Arránz Becker and Lois (2010), investigated the marriage behaviour of East-West German female migrants, and found that East German women have a much lower transition rate into first marriage than western Germans. Arránz Becker and Lois (2010) found that the first marriage behaviour of migrant women from the East resembles that of western German women. This is astonishing, because the migrants are less religious and more employment-oriented than western German women and denomination and employment orientation are believed to be important reasons for the East-West difference in marriage patterns. Obviously, these characteristics do not have the same effect on the migrants' behaviour. While Arránz Becker and Lois (2010) showed that East-West migrants' marriage rates are similar to that of western Germans, they did not find any evidence for either a convergence or a divergence in the marriage behaviours of non-mobile eastern and western Germans over time.

Reasons for the lack of research on East-West German migrants' demographic behaviour are their relatively small number, and the difficulties in identifying the migrants in the available data.

\section{Data, Variables and Methods}

We use data from the German Socio-Economic Panel (GSOEP), monitored by the German Institute for Economic Research in Berlin (Haisken-DeNew and Frick 2005, Wagner et al. 2007). The GSOEP is a household panel starting from 1984 with two 
West German samples: one of residents in the FRG with an initial size of 4,528 households (sample A); and one of households with heads of Turkish, Greek, Yugoslavian, Spanish or Italian origin with an initial size of 1,393 households (sample B). East Germans are covered in sample C of the panel that started in 1990, with 2,179 households. Sample D, with 522 households in 1994/95, is a sample of immigrants who moved to West Germany after 1984. Refreshment samples were added in 1998, with 1,067 households (E); in 2000, with 6,052 households (F); and in 2006, with 1,506 households (H). In 2002, a high-income sample G of 1,224 households was added. The GSOEP offers representative micro-data on persons, couples, households and families on a range of objective and subjective indicators.

For studying internal migration in Germany, the GSOEP is the most comprehensive longitudinal dataset that exists (Farwick 2009). It is the only currently available dataset offering prospective information on various characteristics before and after the move. Furthermore, it allows us to distinguish between original migration and return migration between East and West Germany. Another decisive advantage of the GSOEP for our study is that there is an oversample of East Germans in sample C, and of East-West migrants in sample D.

For this analysis, we use data from the waves of 1990 to 2009 . We drop from the sample all observations for which the year of birth, employment status or the state of current residence is missing; all immigrant groups from the immigrant sample D who are not of eastern German origin; and all observations where the respondent does not have German nationality. In addition, we limit the sample to female respondents aged 16-45. For the models including partner characteristics, we restrict the sample to women with male cohabiting partners. The final sample includes 26,695 person-years and 1,218 events for the analysis of first births, and 15,469 person-years and 968 
events for the analysis of second births (see an overview of the sample in Table A2 in Appendix B).

\section{Variables}

Our focus is on the behaviour of individuals who originate from East Germany and move to West Germany. ${ }^{6}$ In our model, being a resident of either region (East Germany, West Germany) is treated as a time-varying variable. Therefore, respondents can change their status as they change residence, and, depending on their area of origin, can become East-West migrants while under observation. Based on the classifications on origin and the current federal state of residency, we divide our sample into three groups: ${ }^{7}$

- 'West': of western German origin and living in western Germany

- 'East': of eastern German origin and living in eastern Germany

- 'East-West migrants': of eastern German origin and living in western Germany. ${ }^{8}$

We use the official classifications of eastern and western states, with Berlin being separated into an eastern and a western part. Although Berlin is no longer a divided city, differences relevant to our area of study, e.g. regarding child care coverage, remain. Additionally, this definition is consistent with the sample affiliations and the

\footnotetext{
${ }^{6}$ For our definition of migrants, we combine information on the sample affiliation of the respondent, generated information on his place of living before the fall of the Berlin Wall in November 1989 and self-provided information on an educational or vocational degree attained in the GDR. We follow the information on residence before 1989 if it does not conflict with a combination of the other types of information. Furthermore, we categorise respondents as East-West migrants who moved into existing GSOEP households, and members of the Immigrant Sample D, who self-reported coming from East Germany. Persons for whom none of the above-mentioned information applies are dropped from the sample.

${ }^{7}$ The corresponding fourth category of West-East migrants of western German origin and living in eastern Germany is dropped, since this group is too small for a separate investigation.

${ }^{8}$ We drop all observations for periods of return migration.
} 
information on residency before 1989, which might otherwise lead to false migration observations. ${ }^{9}$

Other covariates include the migrant status of the couple, period, age, education, employment and partnership status and the employment status of the partner.

The variable migrant status of the couple is constructed from the migrant status of the respondent and the origin of her partner, and can have the values 'both West', 'both East', 'East-West migrant with East partner', 'East-West migrant with West partner' and 'other'.

We employ the variable partnership status, with the categories of 'single' (including divorced and widowed if the individual does not have a new partner), couples in which the partner lives in another household ('living apart together'), 'cohabiting' and 'married'. We generate the educational degree by referring to the attained school degree. It is differentiated into those with no information on the attained school degree, those with no or a low secondary school degree, those with an intermediate secondary degree and those with an upper secondary school degree. The employment status is defined as still being 'in education' (including vocational education, military service and compulsory or voluntary community service), being 'employed full-time', being 'employed part-time or marginally', being 'unemployed' or being 'inactive' (not employed and not registered as unemployed). The same definition is used for the employment status of the partner.

We also account for value orientations in the model. As a proxy for value orientations, we include religious denomination in the variants 'no denomination', 'Protestant', 'Catholic' and 'other denomination'. To observe possible differences between the groups in work and family orientations, we use respondents' evaluations

\footnotetext{
${ }^{9}$ If a person lived in Berlin (West) before 1989, she would be a 'West-East' migrant without actually moving if we counted the whole of Berlin as belonging to eastern Germany.
} 
of which areas of their life are very important for their satisfaction and well-being. ${ }^{10}$ The items we selected are equally employment-related (i.e. importance of work, income and career success) and centred on the private sphere (i.e. importance of family, children and partnership). ${ }^{11}$ As this information is not collected on a yearly basis, it is projected forward.

\section{Method}

In a first step, we display the fertility patterns of transition to the first and the second birth of eastern and western Germans and of East-West migrants by employing smoothed hazard curves. We then estimate the first and second birth models by Cox models. For the first birth, the process time is the age of the respondent. For the second birth, it is the duration between the first and the second births. As our key interest is in how East-West migrants differ in their fertility behaviour from nonmigrants, we follow a stepwise inclusion of variables in order to detect whether differences between migrants and non-migrants can be attributed to differences in the composition of the populations in terms of their socio-economic characteristics or value orientations. Because family and employment orientation might not be independent, the importance of work, income, career success and children are included separately in the models, with a final model including all dimensions. The models are estimated for all respondents, and, as a subsequent step, for respondents with a male cohabiting partner, where some characteristics of the partner, i.e. origin and employment status, are included along with the respondents' characteristics.

\footnotetext{
10 The original options are 'very important', 'fairly important', 'somewhat important' and 'not important'. Because percentages in the latter three categories are sometimes very low, we grouped them together into one category of 'not very important', thus creating dichotomous variables.

${ }^{11}$ The importance of family and partnership did not show significant effects in either of the models, and are not shown.
} 
The data are set up in long format. All covariates are recorded for each person in the sample in each year he or she took part in the panel. For all analyses, the covariates are lagged by one year to reduce reversed causality. Thus, for a birth, we take into consideration the characteristics of the respondent around the time of conception.

\section{Results}

\subsection{First Birth}

Figure 2 provides estimates of (smoothed) hazard rates to first births. These graphs confirm that eastern German women have higher first birth risks than western German women (Arránz Becker et al. 2010). The migrant status is modelled as timedependent. Therefore, individuals can leave the risk set of eastern Germans and enter that of migrants.

Migrants' first birth risks are lower than those of eastern Germans, and more closely resemble those of West Germans in magnitude, but they experience the highest risks at younger ages than the western Germans. Migrants have the highest risk at age 27, eastern German women at age 29 and western German women at age 31.

\section{[FIGURE 2 ABOUT HERE]}

Table 1 presents the results for a first birth Cox model. In Model 1.1, only the migrant status and period are controlled for. In the subsequent models, partnership status, school degree, employment status and religious denomination are added step-wise to show the influence of the single variables on the effect of origin and mobility covered by the migrant status (Models 1.2-5). Additionally, the respondents' evaluation of the importance of the life areas of work, income, career success and children are separately included into the model in Models 1.6-9, with Model 1.10 including all of

these items. In Table 2, the same models are repeated, but only for women in a 
cohabiting partnership with a male partner. These models include information about the origin of the partner and his employment status.

The first multivariate model shows that the difference between the eastern German and the western German propensities for a first birth is highly significant (see Model 1.1), while the gap between eastern Germans and East-West migrants becomes significant on a 10 per cent level only if the partnership status is controlled for (see Model 1.2). This suggests that more migrants are living in partnerships than are eastern Germans. Their first birth risks are depressed relative to those of eastern Germans because the more institutionalised the relationship is - moving in together, getting married - the higher the risk is of a first birth. The role that mobility plays here is unclear. On the one hand, migration can lead to the disruption of partnerships and difficulties in finding a new partner. However, most migrants in our risk set who are in a cohabiting relationship are coupled with another migrant. ${ }^{12}$ On the other hand, some (unobserved) characteristics that make an individual capable of realising a migration could also make them more likely to find a partner; or, in the case of a couple migrating together, make their relationship stronger. Moreover, East-West migration might be, at least in part, motivated by the wish to move in with or closer to a partner.

Having attained a high school degree is correlated with depressed first birth risks compared to having an intermediate degree (see Model 1.3), but Model 1.4 shows that this effect is due to current enrolment in further education which strongly prevents a first birth. Being religiously affiliated is positively correlated with first birth risks, especially for Catholics, as can be seen in Model 1.5. Including religion makes EastWest differences in first birth risks greater in magnitude, and the differences between

\footnotetext{
${ }^{12}$ See Table A2 in Appendix B.
} 
eastern Germans and migrants to the West more significant. This is because the first birth risks of eastern Germans are highest, even though they are the group with the lowest degree of religious affiliation. The fact that the proportion of the population with no denomination is higher in eastern Germany does not appear to be connected with, or to provide an explanation for, their first birth risks. This contradicts prior findings by Arránz Becker et al. (2010), who showed that being non-denominational promotes the transition to parenthood by accelerating the formation and consolidation of intimate relationships. ${ }^{13}$

While Models 1.6-8 show that being more work-oriented does not greatly influence the first birth risk, regarding children as not very important in one's life lowers the risk of having a child by 41 per cent, as seen in Models 1.9-10. Including child orientation takes away some of the significance of the difference between East Germans and East-West migrants. Thus, migrants' risks of having a first birth are probably lower than those of eastern Germans, partly because children are less important to them, and despite the fact that they are more likely to be in a relationship or to be religiously affiliated.

[TABLE 1 ABOUT HERE]

\section{The role of the partner's characteristics in the first birth}

In the next step, we turn to the first birth risks of women cohabiting with a male partner. In Model 2.1, using couples in eastern Germany in which both partners are from the East as the reference, the migrant status of the couple appears to have no significant role in the risk of experiencing a first birth. The only group that shows a

\footnotetext{
${ }^{13}$ We presume that the differences in the results may be explained by the fact that Arránz-Becker et al. (2010) use a sample that is more selective than ours, and exclude cohorts born before 1970. Analyses not shown here confirm that for these cohorts the positive effect of denomination on birth risks is strongest.
} 
marked difference from the others is the one made up of East-West migrants with partners from the East, among whom there is a lowered risk.

From Model 2.2 we can see that being married raises the risk of a first birth. The attained school degree does not have an effect on the first birth risks of the women cohabiting with a male partner (see Model 2.3), but current enrolment in education both of the respondent and of the partner - lowers the risk of a first birth for cohabiting women (see Model 2.4). As in the individual model, controlling for religious affiliation makes the differences between the eastern and the western nonmobiles apparent (see Model 2.5). The first birth risks of western Germans would be significantly lower than those of eastern Germans if the distribution of religious denominations were the same in both populations. While work does not play an important role for the first birth risks of women in a cohabiting partnership (see Model 2.6), we can see that their birth risks are lower if they highly value income (see Model 2.7), and especially if they value career success (see Model 2.8). The latter plays a role for the 'other' group of couples, who have a lower birth risk when career orientation is controlled for. That is, their birth risks would have been lower if they were as career-oriented as eastern Germans, which they are not. Considering that women with a non-German partner are included in this group, this seems plausible. Model 2.9 shows that controlling for the subjective value of children takes away from the positive effect of being Protestant on first birth risks, which suggest that these two measures are correlated. Work and family orientation retain their influence on first birth risks when they are simultaneously controlled for (see Model 2.10).

Taking into account all covariates, we can see that couples that are comprised of western Germans, East-West migrants and 'other' combinations have lower first birth risks than eastern German couples. We do not see a significant difference from 
eastern Germans in the first birth risks of couples living in the West in which the woman is from eastern Germany and the man is from western Germany.

\section{[TABLE 2 ABOUT HERE]}

\subsection{Second Birth}

For second births, we have in many respects the reverse of the situation found for first births. Figure 3 confirms that Western Germans and East-West migrants, once they have had a first child, have a higher likelihood of having a second child, while eastern Germans often stop at one. For western Germans and migrants to the West, the risk of having a second child is highest four years after the first child is born. For eastern Germans the risk curve is less steep, and peaks at five years after the first child is born. The migrants show an intermediate pattern.

\section{[FIGURE 3 ABOUT HERE]}

In the next step, we turn to the multivariate analysis. Tables 3 and 4 show the same models we estimated for the first birth for women's risk of having a second birth; based on their individual characteristics only in Table 3, and including information about their partners in Table 4. These models are controlled for period and age groups.

Controlling solely for period and age groups in Model 3.1 in Table 3, western Germans are shown to have a second birth risk that is 72 per cent higher, and EastWest migrants have a second birth risk that is 31 per cent higher than that of eastern Germans, with both effects being significant. A portion of these differences are explained by the partnership status, as can be seen in Model 3.2. As for the first birth, birth risks are positively correlated with the partnership status. Eastern Germans are less likely than the other two groups to be married after having a first child, and their 
second birth risks are correspondingly lower. The higher the level of education, the higher are the second birth risks (see Model 3.3). In contrast to the effects observed for first births, the school degree does not lose its impact if the employment status is introduced in the model, and educational participation has a significant positive impact on second birth rates (see Model 3.4). In this context, it is important to note, however, that the share of one-child mothers who are in education is small. ${ }^{14} \mathrm{We}$ find reduced second birth risks for full-time employed women. The elevated second birth risks among western German women and migrants are hence related to these women being less likely to be in full-time employment. ${ }^{15}$ Women who work full-time have the lowest propensity to have a second child. Migrants seem to adapt to the typical western German employment pattern, in which mothers are not in full-time employment. Whether this expresses a choice to focus on the family, or difficulties in reconciling employment and motherhood, is not clear.

As for first births, being religiously affiliated raises second birth risks (see Model 3.5); but, unlike for first births, religious affiliation explains only a portion of the differences in birth risks between eastern and western German women. All religiously affiliated groups have significantly elevated second birth risks. The inclusion of the denomination further reduces the East-West difference, but does not alter differences between eastern Germans and migrants. This suggests that migrants partly adapt to western Germans in their fertility behaviour, but do not adapt in terms of religious affiliation.

Controlling for work orientation - specifically, the subjective importance of work and income - further diminishes differences between the eastern, western and East-West migrant women. Regarding the importance of work (see Model 3.6) and especially

\footnotetext{
${ }^{14}$ See Table A2 in Appendix B.

${ }^{15}$ See Table A2 in Appendix B.
} 
income (see Model 3.7) as not very important are positively associated with second birth risks. Including the subjective importance of income renders East-West differences insignificant. If work and income were more important to western women and migrants, their second birth risks would be lower, and they would be more similar to those of eastern German women. The importance of career success, on the other hand, does not have an effect on the second birth risks (see Model 3.8). For eastern German women, children are more important than for western German women, but East Germans still have lower second birth risks (see Model 3.9).

While regarding children as not very important is negatively associated with second and first birth risks, the importance of employment-related values only affects second birth risks. Financial orientation is more influential on second birth risks than orientation towards children (see Model 3.10), but it does not have a strong influence on family formation.

Including all of the covariates, second birth risks are elevated by 19 per cent for western Germans and by 11 per cent for East-West migrants, compared to eastern Germans, among whom none of the effects are significant. The differences between the three groups are largely explained by differences in partnership status, employment status, religious denomination and orientations towards employment and income. School degree and family orientation, on the other hand, magnify East-West differences, without affecting differences between eastern Germans and migrants.

[TABLE 3 ABOUT HERE]

\section{The role of the partner's characteristics in the second birth}

In the following, we will look at the models for the second birth risks of women in cohabiting heterosexual partnerships, shown in Table 4. In Model 4.1, three groups 
have significantly elevated risks compared to women in eastern German couples: those in western German couples, those in an East-West migrant couple and those who are 'others', including women with a non-German or West-East migrant partner. There are no differences in second birth risks between East-West migrant women coupled with a western German man and the reference group of eastern German couples. In Model 4.2, we see that after controlling for marital status, the differences between the groups, in particular between the couples of two eastern Germans and the others gets smaller. On the other hand, the differences to the other groups are enhanced again if we include school degrees. A high school degree is correlated with elevated second birth risks and a low degree with depressed second birth risks, compared to an intermediate degree (see Model 4.3). The low second birth risks of the eastern German couples are connected to their employment status, as Model 4.4 shows. Full-time employed women have the lowest and inactive women and those enrolled in education have the highest risks to experience a second birth. While the employment status of the woman is strongly correlated with birth risks, that of the partner seems to be insignificant. Being religiously affiliated is positively correlated with the second birth risks of coupled women (see Model 4.5). Controlling for religious affiliation lowers the risks of western German couples and of 'others' relative to eastern German couples, but it does not affect differences in risks between eastern German couples and those in which the woman is an East-West migrant.

All work-related orientation items - i.e. placing a high value on work (see Model 4.6), income (see Model 4.7) and career success (see Model 4.8) - are negatively correlated with second birth risks. Preference for income dominates over the effects of work and career success preference, as Model 4.10 shows. The East-West differences would be smaller if work, success in employment and especially income were seen to be as 
important to women in western German couples as they are to women in eastern German couples. While seeing children as very important is positively correlated with second birth risks, it does not alter the relative risks of migrant groups (see Model 4.9). The driving factor in orientation in that respect is that of importance of income (see Model 4.10).When all of the covariates are included, western German couples' second birth risks are raised by 23 per cent, migrant couples' risks are elevated by 42 per cent and 'other' couples' risks are raised by 39 per cent; relative to those of eastern German couples. East-West German women with a partner from the West do not - contrary to our assumptions - adapt more readily to the western German pattern. They do not seem to differ greatly from the eastern German couples. However, due to a particularly small sample size for this group, the results should be interpreted with caution.

[TABLE 4 ABOUT HERE]

\section{Summary and Discussion}

In this analysis, we wanted to find out how migrants from the eastern to the western German states differ in their fertility behaviour from the non-mobile populations in the East and the West. Migrants were hypothesised to either act in line with their socialisation in the East, to adapt to the West German behavioural patterns or to act as a special - i.e. selected - group. To control for differences in adaptation between migrants with partners from the East and the West, models including the origin of the partner were estimated.

We find that the fertility behaviour of East-West migrants differs from that of the eastern Germans still living in eastern Germany, and from that of western Germans. While we do not find a (significant) difference between the first birth risks of eastern 
Germans and East-West migrants in a model without covariates, the difference between the behaviour of those two groups becomes clearer as we control for union status and religious denomination. Migrants have comparable first birth risks to nonmobile eastern Germans, but they are also more likely to be in a stable partnership and to be religiously affiliated, which boosts the risk of family formation. If these characteristics are controlled for, migrants' first birth risks are actually lower than those of eastern Germans, although not as low as those of western Germans. On these grounds we can refute the selection hypothesis for first births. Migrants are a special group, but this is not the reason for their divergent family formation behaviour. Controlling for employment and family related preferences rather explains East-West differences than differences between eastern Germans and migrants. However, for second births, a large portion of the difference in birth risks between eastern Germans and East-West migrants - but also between eastern and western Germans - is explained by religious affiliation and employment orientations. The second birth risks would converge to a great extent if employment patterns, religious affiliations and preferences for work and income were the same across the populations.

There is no evidence that having a partner from the West accelerates the adaptation of the migrants. Mobile women with a partner from the West display higher first birth risks and lower second birth risks than those migrants with a partner of eastern German origin.

We conclude that the depressed first birth and elevated second birth risks of the EastWest migrants in comparison to non-mobile eastern German women cannot be attributed to selection. This is especially true for the first birth, while differences in second birth risks can partially be dissolved by controlling for socio-economic characteristics and value orientations of the migrants. 


\section{References}

Alheit, P. 2005: Modernisierungsblockaden in Ostdeutschland? 15 Jahre deutsche Einheit. Aus Politik und Zeitgeschichte 40, 32-40.

Andersson, G. and K. Scott 2007: Childbearing dynamics of couples in a universalistic welfare state: The role of labor-market status, country of origin, and gender. In: Demographic Research 17(30), 897-938.

Arránz Becker, O. and D. Lois 2010: Unterschiede im Heiratsverhalten westdeutscher, ostdeutscher und mobiler Frauen: Zur Bedeutung von Transformationsfolgen und soziokulturellen Orientierungen. Soziale Welt 61, 526.

Arránz Becker, O., Lois. D. and B. Nauck 2010: Differences in fertility patterns between East and West German women: Disentangling the roles of cultural background and of the transformation process. Comparative Population Studies - Zeitschrift für Bevölkerungswissenschaft 35(1), 7-34.

Bernardi, L., Klärner, A. and H. von der Lippe 2008: Job insecurity and the timing of parenthood: A comparison between Eastern and Western Germany. In: European Journal of Population 24, 287-313.

Boyle, P.J., Kulu, H., Cooke, T., Gayle, V. and C.H. Mulder 2008: Moving and union dissolution. Demography 45(1), 209-222.

Brehmer, W., Klenner, C. and U. Klammer 2010: Wenn Frauen das Geld verdienen: Eine empirische Annäherung an das Phänomen der "Familienernährerin". WSI Diskussionspapiere 170.

Brück, T. and H. Peters 2009: 20 years of German Unification: Evidence on income convergence and heterogeneity. IZA DP 4454.

Brücker, H. and P. Trübswetter 2004: Do the best go West? An analysis of the selfselection of employed East-West migrants in Germany. IZA DP 986.

Büchel, F. and J. Schwarze 1994: Die Migration von Ost- nach Westdeutschland: Absicht und Realisierung. Mitteilungen aus der Arbeitsmarkt- und Berufsforschung 27.

Dorbritz, J. and K. Ruckdeschel 2009: Die langsame Annäherung: Demografisch relevante Einstellungsunterschiede und der Wandel der Lebensformen in Westund Ostdeutschland. In: Cassens, I., M. Luy and R. Scholz (eds.): Die Bevölkerung in Ost-und Westdeutschland: Demografische, gesellschaftliche und wirtschaftliche Entwicklungen seit der Wende. Wiesbaden: VS Verlag für Sozialwissenschaften, 261-294.

Farwick, A. 2009: Internal migration. Challenges and perspectives for the research infrastructure. RatSWD Working Paper 97.

Frejka, T. 2008: Determinants of family formation and childbearing during the societal transition in Central and Eastern Europe. Demographic Research 19(7), 139-170.

Fuchs-Schündeln, N. and M. Schündeln 2009: Who stays, who goes, who returns? East-West migration within Germany since reunification. Economics of Transition 17(4), 703-738. 
Geißler, R. 2004: Struktur und Entwicklung der Bevölkerung. Informationen zur politischen Bildung 269, http://www.bpb.de/publikationen/7WF4KK,2,0,Struktur_und_Entwicklung_der _Bev\%F6lkerung.html\#art2

Gernandt, J. and F. Pfeiffer 2008: Wage convergence and inequality after Unification: (East) Germany in transition. SOEPpaper 107.

Haisken-DeNew, J. P. and J. R. Frick (eds.) 2005: Desktop companion to the German Socio-EconomicPanel (SOEP) - Version 8.0. Berlin: http://www.diw.de/deutsch/sop/service/dtc/dtc.pdf.

Heiland, F. 2004: Trends in East-West German migration from 1989 to 2002. Demographic Research 11(7), 173-194.

Huinink J. and D. Konietzka 2007: Familiensoziologie: Eine Einführung. Frankfurt/Main: Campus Verlag.

Hunt, J. 2000: Why do people still live in Eastern Germany. IZA Discussion Paper 123.

Kley, S. 2010: Explaining the stages of migration within a life-course framework. European Sociological Review (published online).

Klüsener, S. and J.R. Goldstein 2009: Räumliche Analyse des Geburtenverhaltens in Deutschland in Geschichte und Gegenwart: Die Integration soziologischer, geografischer und historischer Forschungsansätze. In: Max-Planck-Gesellschaft/ Generalverwaltung (ed.): Jahrbuch der Max-Planck-Gesellschaft 2008. München: Max-Planck-Gesellschaft, http://www.mpg.de/jahrbuch/forschungsbericht?obj=366170

Klüsener, S. and M. Kreyenfeld 2009: Nichteheliche Geburten im regionalen Vergleich. In: Nationalatlas aktuell 10. Leipzig: Leibniz-Institut für Länderkunde (IfL).

Kreyenfeld, M. 2003: Crisis or adaptation - reconsidered: A comparison of East and West German fertility patterns in the first six years after the 'Wende'. European Journal of Population 19, 303-329.

Kreyenfeld, M. and E. Geisler 2006: Müttererwerbstätigkeit in Ost- und Westdeutschland. Zeitschrift für Familienforschung 18(3), 333-360.

Kreyenfeld, M. and D. Konietzka 2008: Bleibt alles anders: Geburten- und Familienentwicklung in Ost- und Westdeutschland. In: Werz, N. (ed.): Demografischer Wandel. Baden-Baden: Nomos, 50-70.

Kreyenfeld, M. and D. Konietzka 2010: Nichteheliche Geburten. In: Goldstein, J.R., Kreyenfeld, M., Huinink, J., Konietzka, D. and H. Trappe (eds.): Familie und Partnerschaft in Ost- und Westdeutschland: Ergebnisse im Rahmen des Projektes 'Demographic Differences in Life Course Dynamics in Eastern and Western Germany'. Rostock: Max-Planck-Institut für demografische Forschung, 8-9.

Kreyenfeld, M. and S. Krapf 2010: Soziale Ungleichheit und Kinderbetreuung: Eine Analyse der sozialen und ökonomischen Determinanten der Nutzung von Kindertageseinrichtungen. In: Becker, R. and W. Lauterbach (eds.): Bildung als 
Privileg: Erklärungen und Befunde zu den Ursachen der Bildungsungleichheit. Wiesbaden: VS Verlag für Sozialwissenschaften, 107-128.

Kreyenfeld, M., Scholz, R, Peters, F. and I. Wlosnewski 2010: The German Birth Order Register: Order-specific data generated from perinatal statistics and statistics on out-of-hospital births 2001-2008. MPIDR working paper 2010-10.

Kröhnert, S. and R. Klingholz 2007: Not am Mann: Vom Helder der Arbeit zur neuen Unterschicht? Lebenslagen junger Erwachsener in wirtschaftlichen Abstiegsregionen der neuen Bundesländer. Berlin: Berlin-Institut für Bevölkerung und Entwicklung.

Kröhnert, S. 2009: Ausprägung und Ursachen geschlechtsselektiver Abwanderung aus den neuen Bundesländern (Dissertation). Berlin: Humboldt-Universität zu Berlin.

Kulu, H. 2004: Fertility of internal migrants: Comparison between Austria and Poland. MPIDR Working Paper 2004-22.

Kulu, H. 2005: Migration and fertility: Competing hypotheses re-examined. European Journal of Population 21, 51-87.

Kulu, H. and N. Milewski 2007: Family change and migration in the life course: An introduction. Demographic Research 17(19), 567-590.

Mai, R. and M. Scharein 2009: Effekte der Binnenmigration auf die Bevölkerungsentwicklung und Alterung in den Bundesländern. In: Cassens, I., M. Luy and R. Scholz (eds.): Die Bevölkerung in Ost-und Westdeutschland: Demografische, gesellschaftliche und wirtschaftliche Entwicklungen seit der Wende. Wiesbaden: VS Verlag für Sozialwissenschaften, 75-99.

Mayer, K.U. and E. Schulze 2009: Die Wendegeneration: Lebensverläufe des Jahrgangs 1971. Frankfurt am Main: Campus.

Milewski, N. 2007: First child of immigrant workers and their descendants in West Germany: Interrelation of events, disruption or adaptation? Demographic Research 17(29), 859-896.

Milewski, N. 2009: Fertility of immigrants: A two-generational approach in Germany. Demographic Research Monographs No. 6.

Mulder, C. 1993: Migration dynamics: A life course approach. Amsterdam: Thesis Publishers.

Mussino, E. and A. van Raalte 2008: Fertility of migrants: A comparative study between Italy and Russia. MPIDR Working Paper 2008-026.

Okun, B.S. and Kagya, S. 2011: Fertility change among immigrants to Israel from the Former Soviet Union. Working Paper of the Department of Sociology and Anthropology at The Hebrew University of Jerusalem.

Schmid, S. and M. Kohls 2009: Reproductive behaviour of migrant women in Germany: Data, patterns and determinants. Vienna Yearbook of Population research 2009, 39-61.

Schneider, N.F., Ruppenthal, S., Lück, D., Rüger, H. and A. Dauber 2008: Germany: A country of locally attached but highly mobile people. In: Schneider, N.F. and G. Meil (eds.): Mobile living across Europe I. Relevance and diversity of jobrelated spatial mobility in six European countries. Opladen: Budrich, 105-147. 
Seifert, Wolfgang 1997: Integration of „old“ and „new“ immigrant groups in Germany. Vierteljahreshefte der Wirtschaftsforschung 66(1),159-168.

Sobotka, T. 2008: The rising importance of migrants for childbearing in Europe. Demographic Research 19(9), 225-248.

Stauder, J. 2010: Regionale Ungleichhheit auf dem Partnermarkt? Die makrostrukturellen Rahmenbedingungen der Partnerwahl in regionaler Perspektive. Forthcoming in Soziale Welt.

Wagner, G.G., Frick, J. R. and J. Schupp 2007: The German Socio-Economic Panel Study (SOEP): Scope, evolution and enhancements. SOEPpaper 1.

White, M.L., Moreno, L. and S. Guo 1995: The interrelation of fertility and geographic mobility in Peru: A hazards model analysis. International Migration Review 29(2), 492-514.

Willekens F.J. 1991: Understanding the interdependence between parallel careers. In: Jacques J. Siegers, J.J., de Jong-Gierveld, J. and E. van Imhoff (eds.) Female labour market behaviour and fertility: A rational-choice approach. Berlin/ Heidelberg: Springer-Verlag, 11-31.

Windzio, M. 2008: The "exit option" of labour migration from East to WestGermany.: Individual and contextual determinants of geographic mobility of unemployed workers. Migremus Working Paper 2/2008.

Zaiceva, A. 2010: East-west migration and gender: Is there a differential effect for migrant women? Labour Economics 17(2), 443-454. 


\section{Tables and Figures}

Figure 1: Migration loss and net migration from eastern to western Germany, 19912008; excluding Berlin

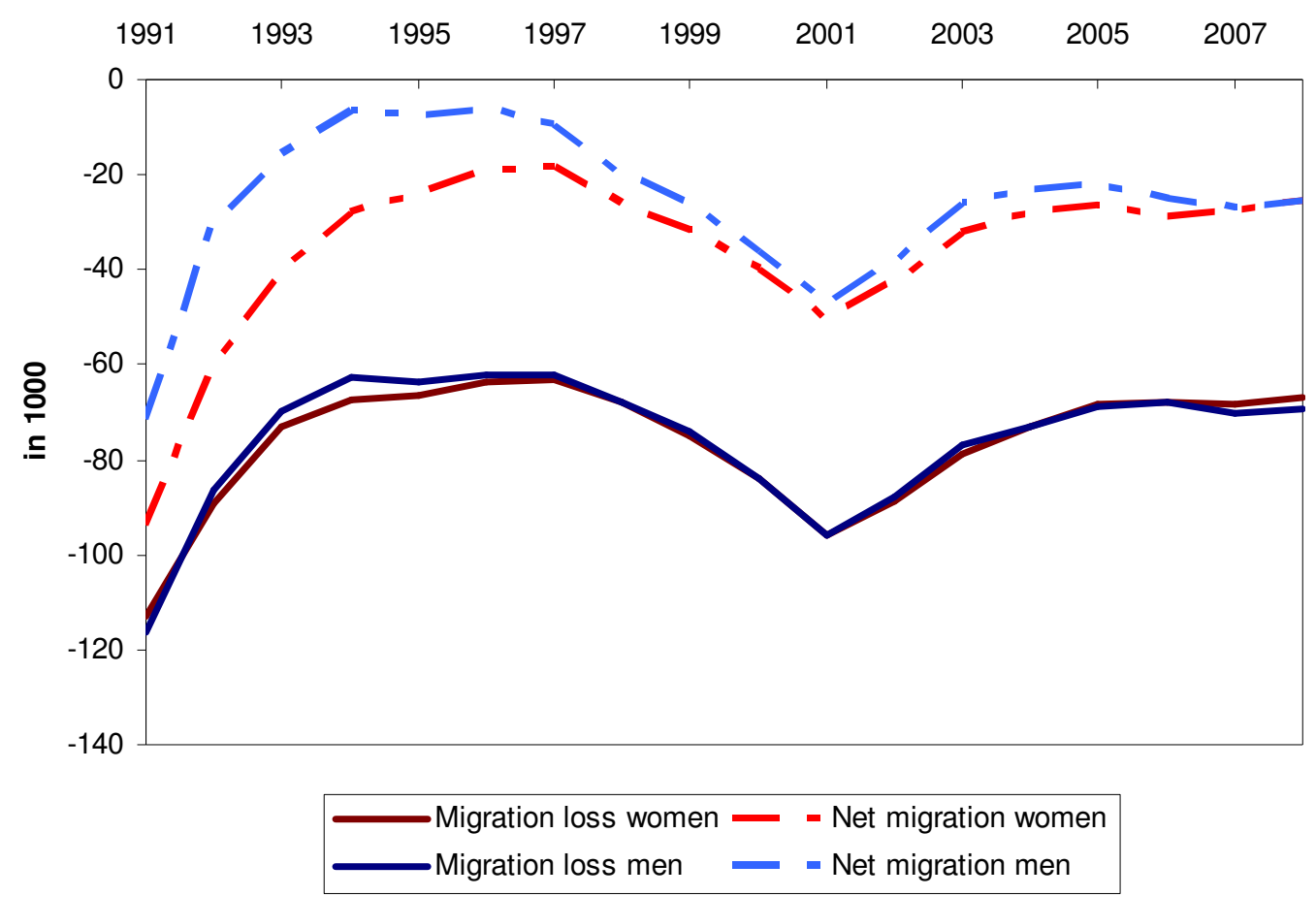

Source: German Federal Statistical Office (own illustration) 
Figure 2: Hazard Rates for transition to first birth by migrant status

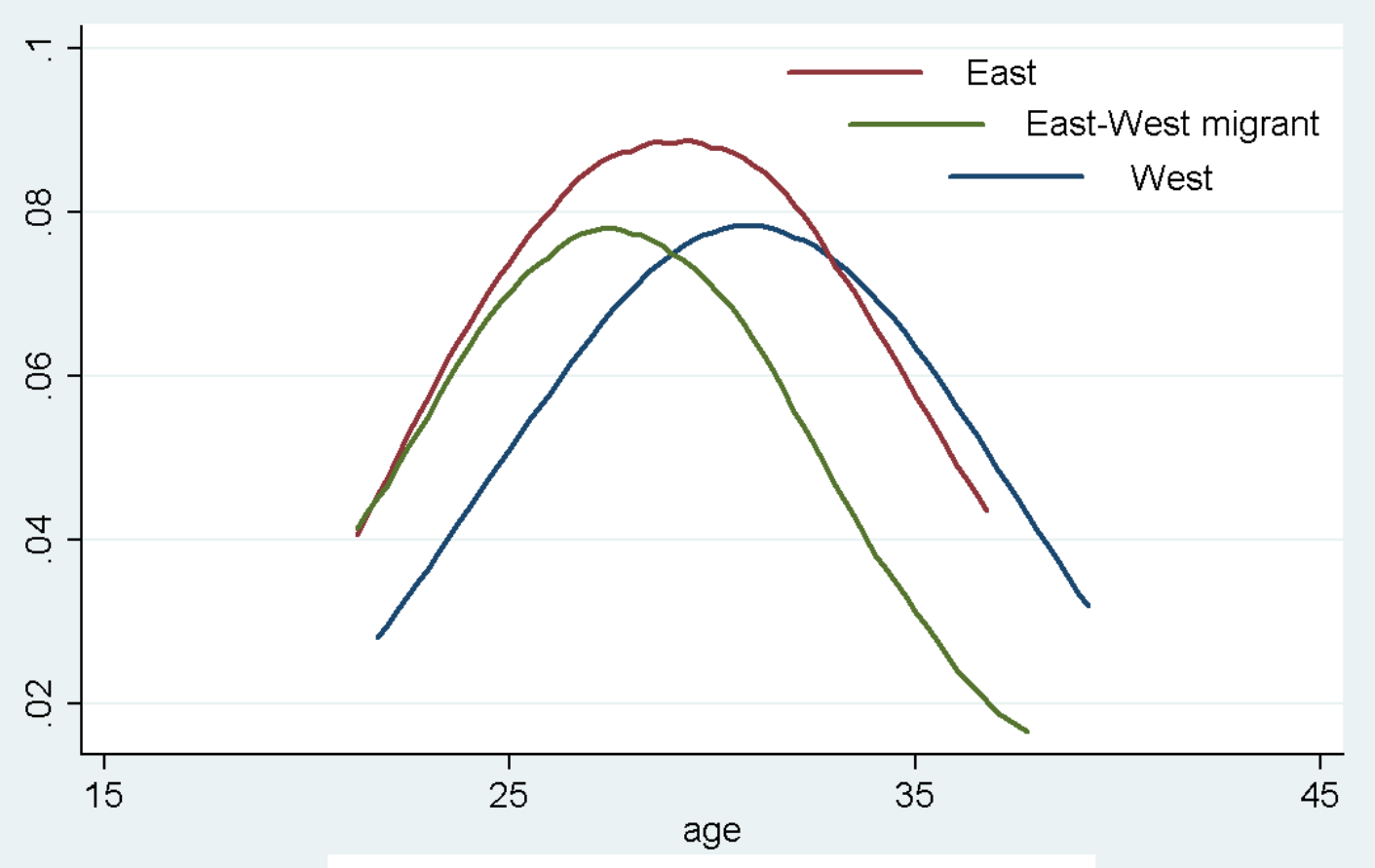

(GSOEP 2009, own estimations) 
Figure 3: Hazard Rates for transition to second birth by migrant status ${ }^{16}$

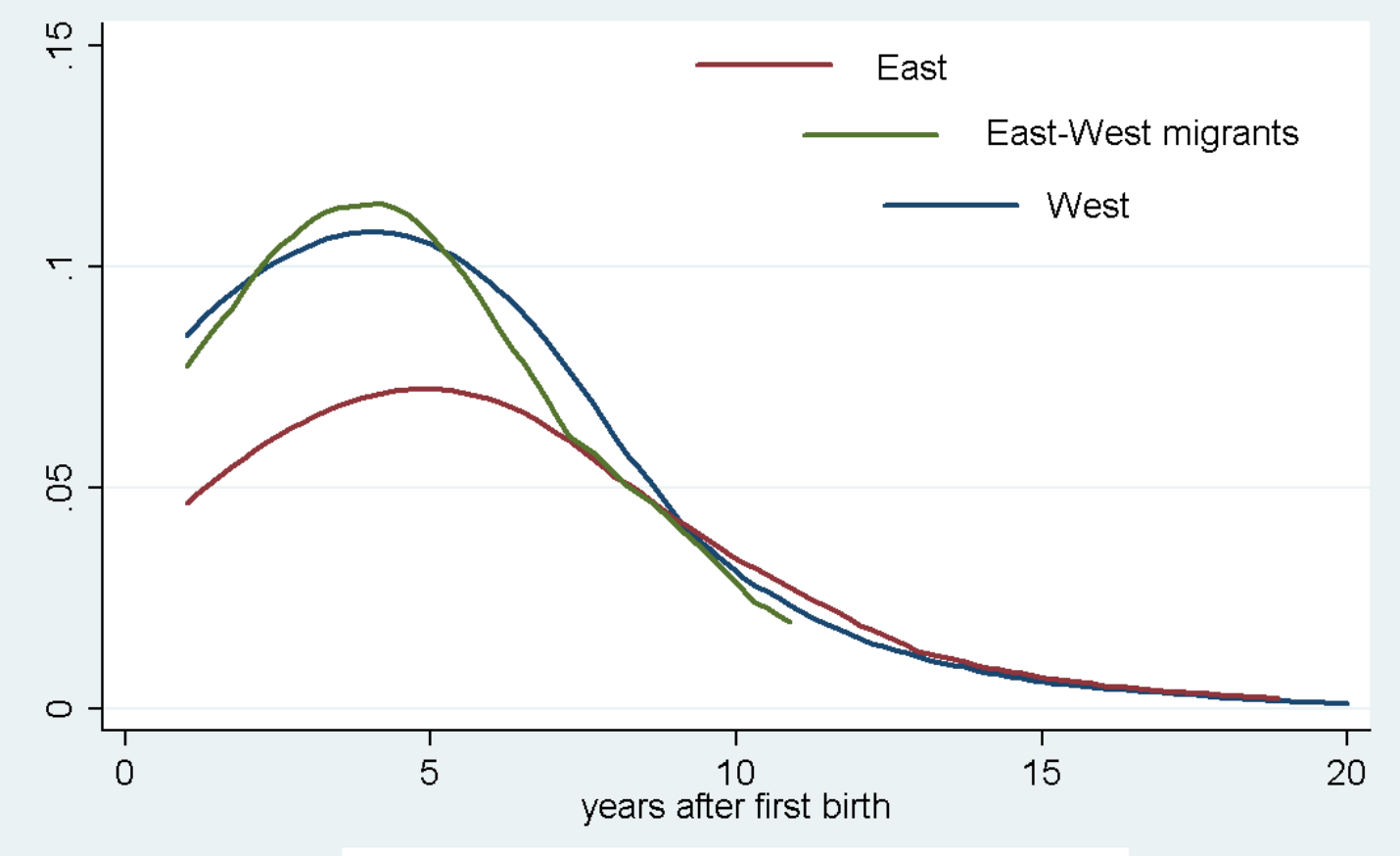

(GSOEP 2009, own estimations)

${ }^{16}$ Hazard rates start one year after the first birth, since we do not allow for multiple births. 
Table 1: Relative risks of first birth, Cox model, women aged 16-45

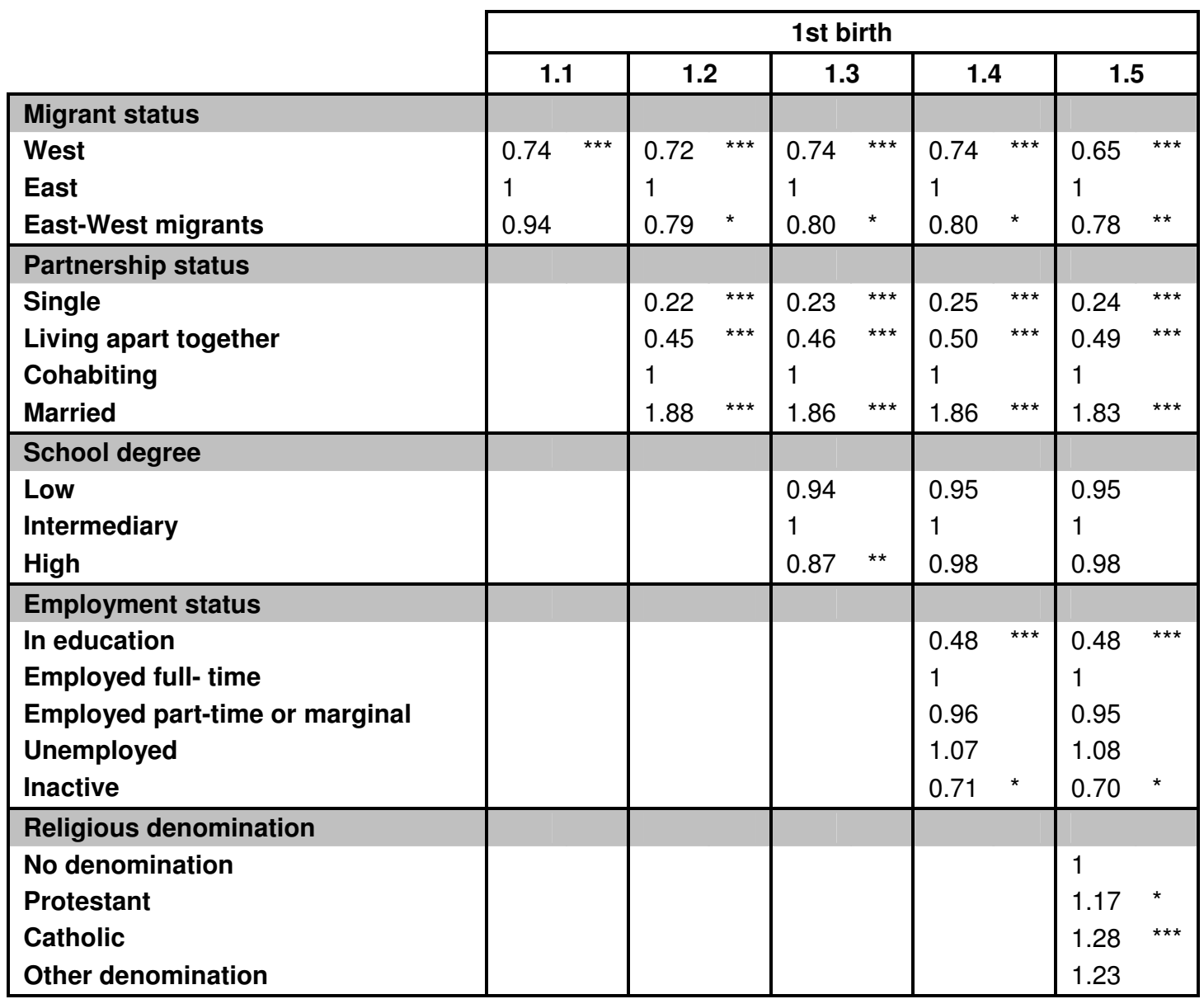

controlled for period

\begin{tabular}{|c|c|c|c|c|c|}
\hline & \multicolumn{5}{|c|}{ 1st birth } \\
\hline & 1.6 & 1.7 & 1.8 & 1.9 & 1.10 \\
\hline Migrant status & & & & & \\
\hline West & $0.65^{* * *}$ & $0.64^{* * *}$ & $0.63^{* * *}$ & $0.66^{\star \star * *}$ & 0.65 \\
\hline East & & & & & \\
\hline East-West migrants & $0.78 \quad * *$ & $0.78 \quad * *$ & 0.78 & 0.80 & 0.79 \\
\hline \multicolumn{6}{|c|}{ Importance of life areas } \\
\hline \multicolumn{6}{|c|}{ Work } \\
\hline $\begin{array}{l}\text { Very important } \\
\text { Not very important }\end{array}$ & $\begin{array}{l}1 \\
1.04\end{array}$ & & & & $\begin{array}{l}1 \\
1.01\end{array}$ \\
\hline \multicolumn{6}{|l|}{ Income } \\
\hline $\begin{array}{l}\text { Very important } \\
\text { Not very important }\end{array}$ & & $\begin{array}{l}1 \\
1.12\end{array}$ & & & $\begin{array}{l}1 \\
1.12\end{array}$ \\
\hline \multicolumn{6}{|l|}{ Career success } \\
\hline $\begin{array}{l}\text { Very important } \\
\text { Not very important }\end{array}$ & & & $\begin{array}{l}1 \\
1.10\end{array}$ & & $\begin{array}{l}1 \\
1.11\end{array}$ \\
\hline \multicolumn{6}{|l|}{ Children } \\
\hline $\begin{array}{l}\text { Very important } \\
\text { Not very important }\end{array}$ & & & & $\begin{array}{l}1 \\
0.59 \quad * \star *\end{array}$ & $\begin{array}{l}1 \\
0.59 \quad * \star *\end{array}$ \\
\hline
\end{tabular}

controlled for period, partnership status, school degree, employment status, religious denomination ${ }^{* \star *} p \leq 0.01 ;{ }^{* *} 0.01 \leq p \leq 0.05 ;{ }^{*} 0.05 \leq p \leq 0.1 ; 26012$ episodes with 1218 events

(GSOEP 2009, own estimations) 
Table 2: Relative risks of first birth, Cox model, women aged 16-45, with male cohabiting partner

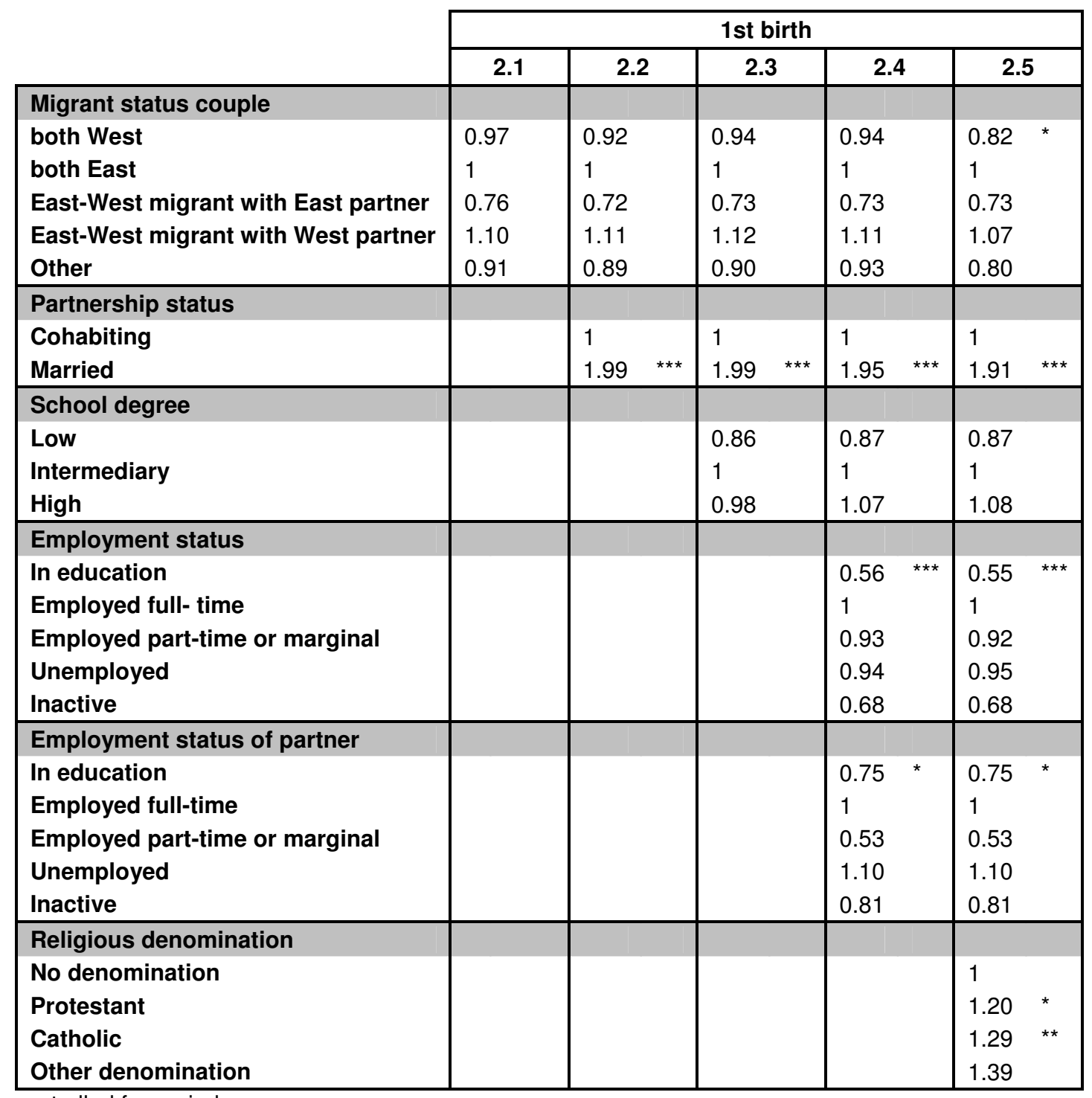

controlled for period 
Table 2: Relative risks of first birth, Cox model, women aged 16-45, with male cohabiting partner (continued)

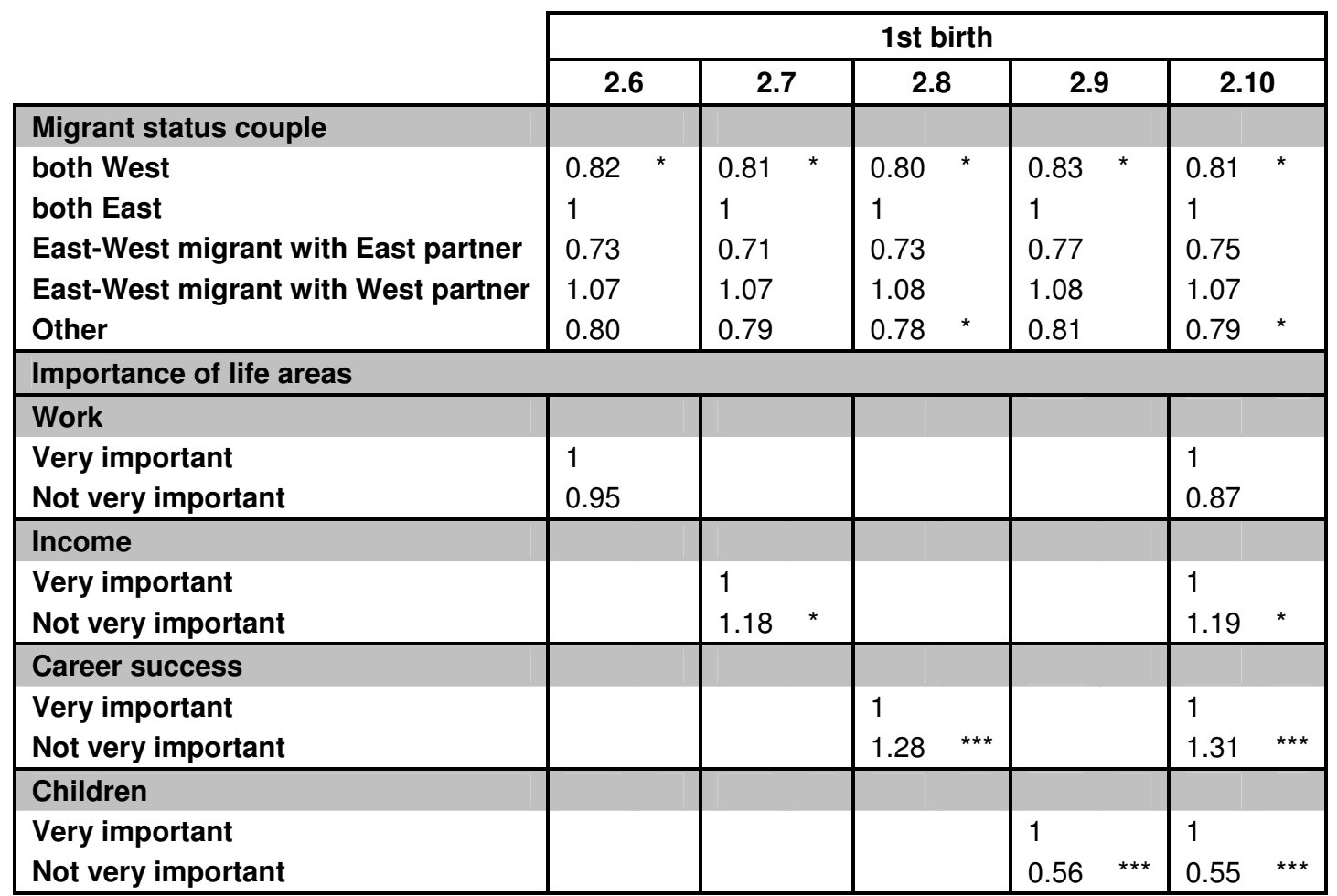

controlled for period, partnership status, school degree, employment status, employment status of partner, religious denomination

${ }^{* * *} p \leq 0.01 ;{ }^{* *} 0.01 \leq p \leq 0.05 ;{ }^{*} 0.05 \leq p \leq 0.1 ; 9293$ episodes with 876 events

(GSOEP 2009, own estimations) 
Table 3: Relative risks of second birth, Cox model, women aged 16-45

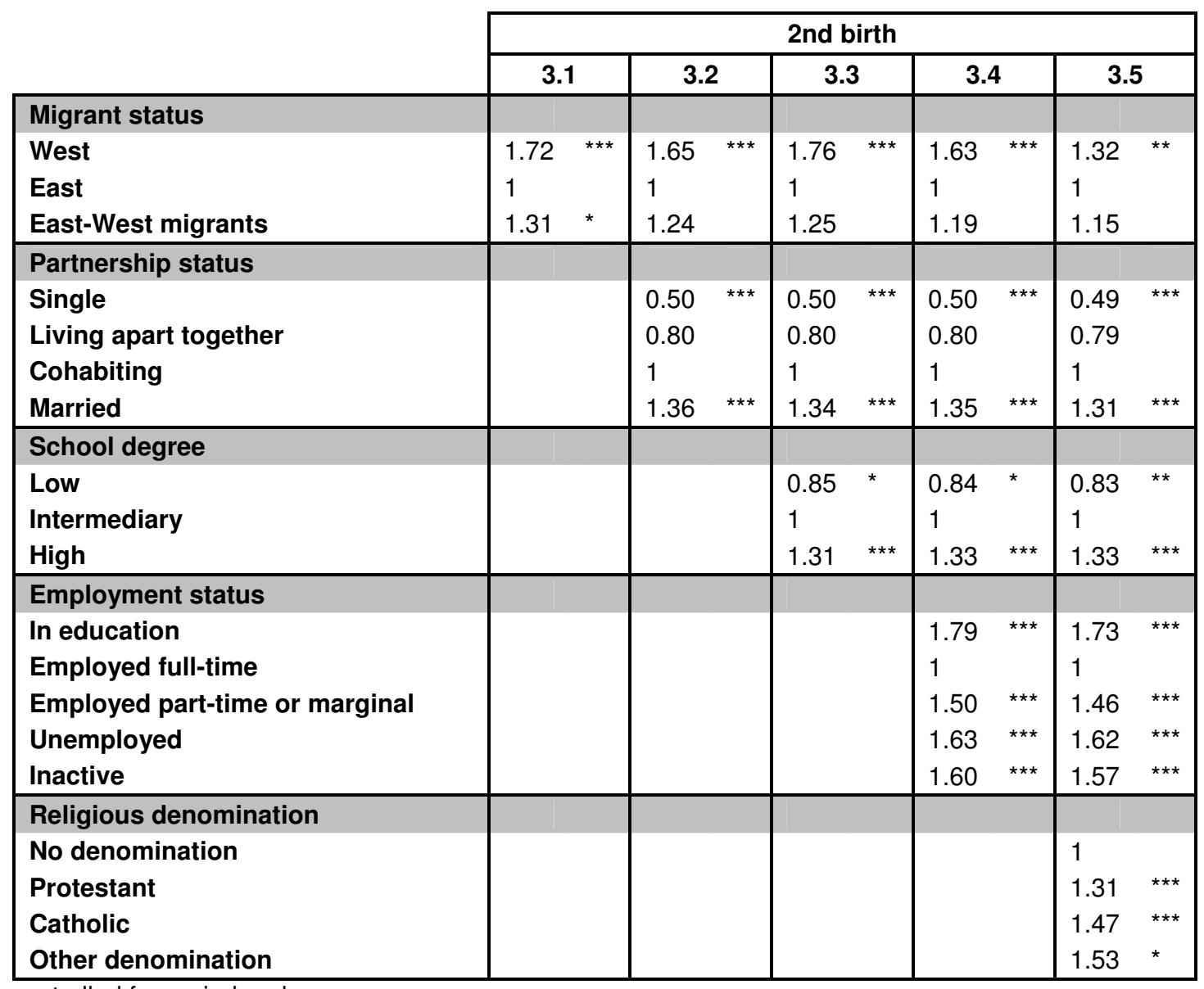

controlled for period and age group

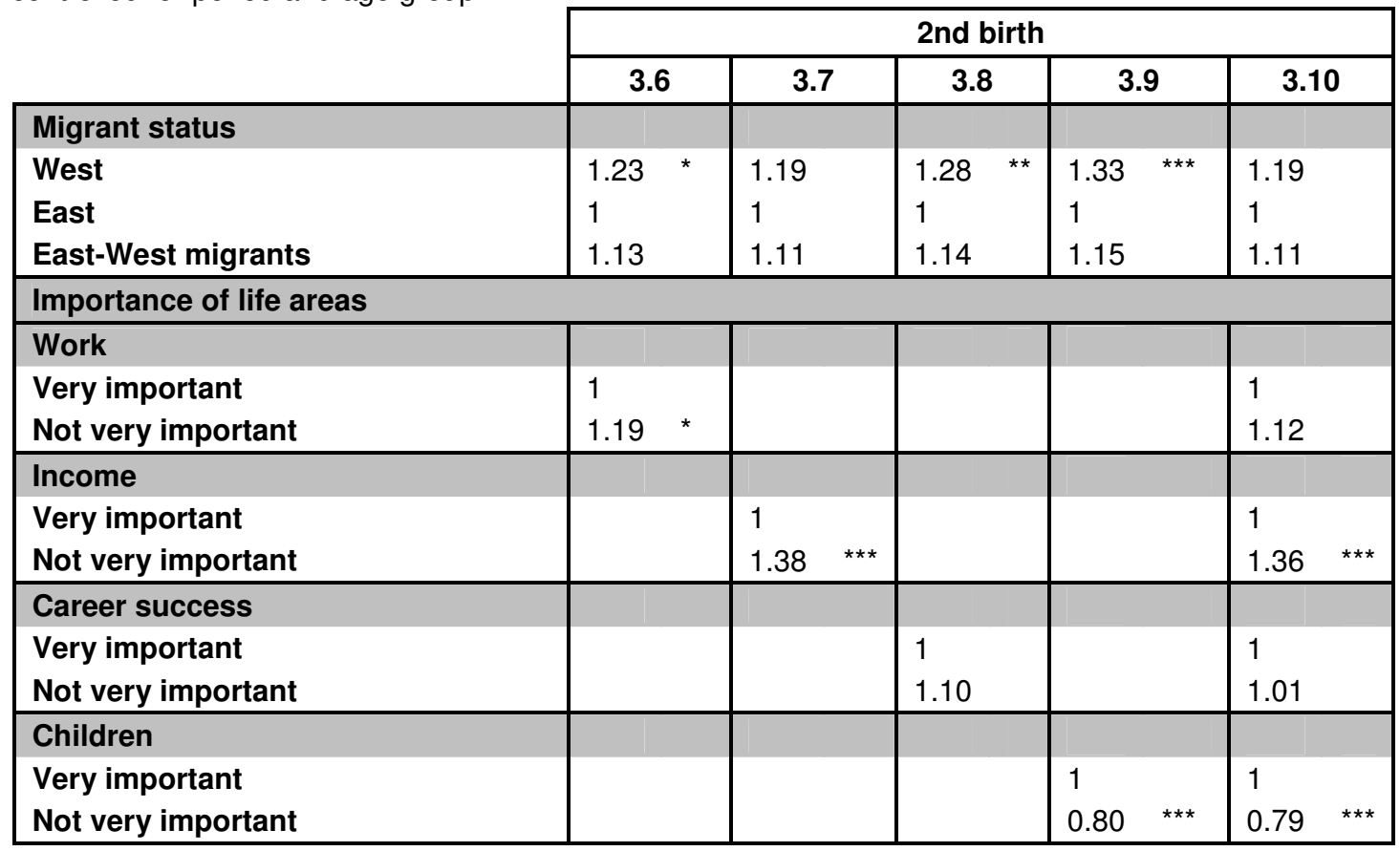

controlled for period and age group, partnership status, school degree, employment status, religious denomination

${ }^{* * *} p \leq 0.01 ;{ }^{* *} 0.01 \leq p \leq 0.05 ;{ }^{*} 0.05 \leq p \leq 0.1 ; 13914$ episodes with 968 events

(GSOEP 2009, own estimations) 
Table 4: Relative risks of second birth, Cox model, women aged 16-45, with male cohabiting partner

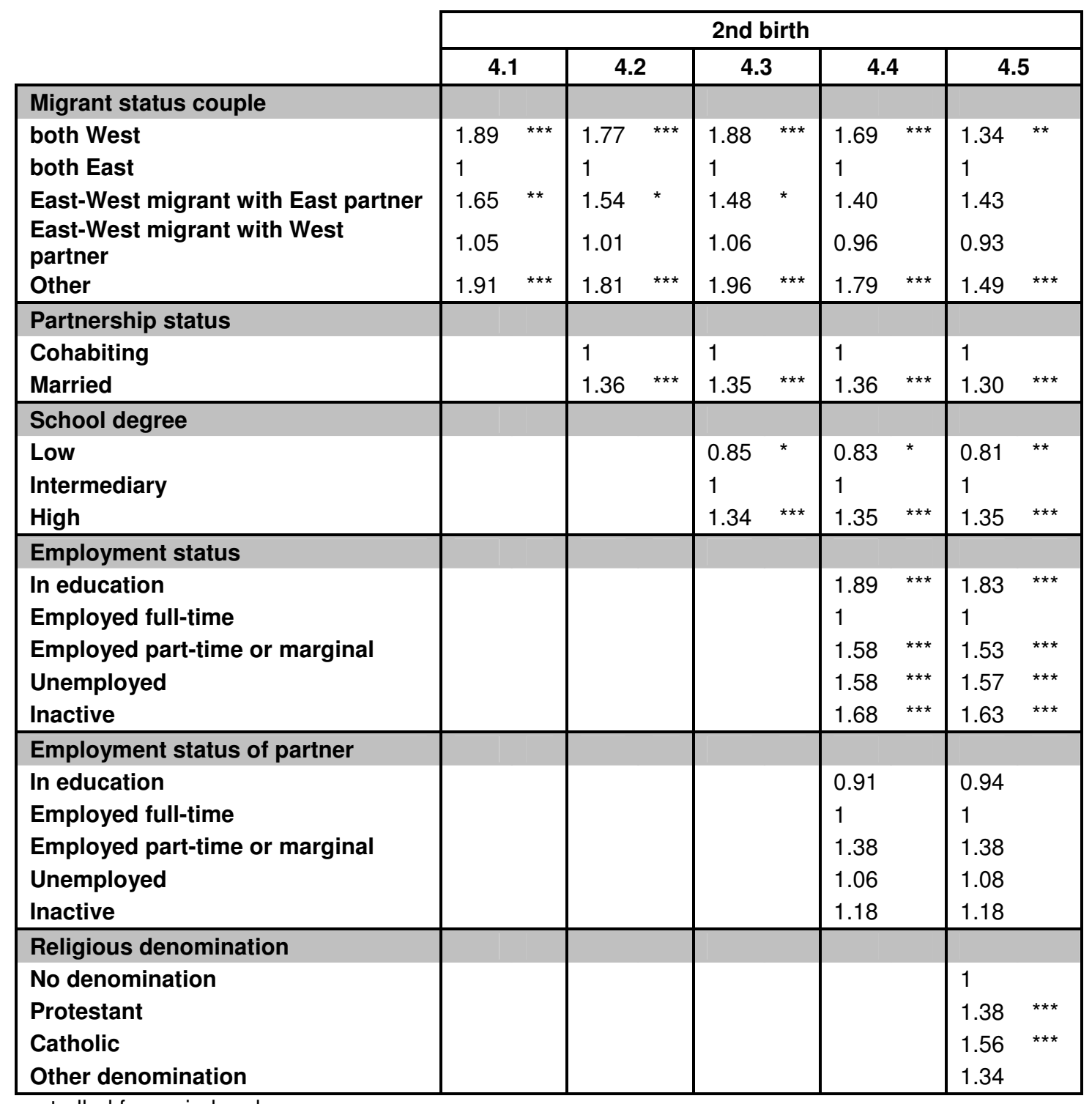

controlled for period and age group 
Table 4: Relative risks of second birth, Cox model, women aged 16-45, with male cohabiting partner (continued)

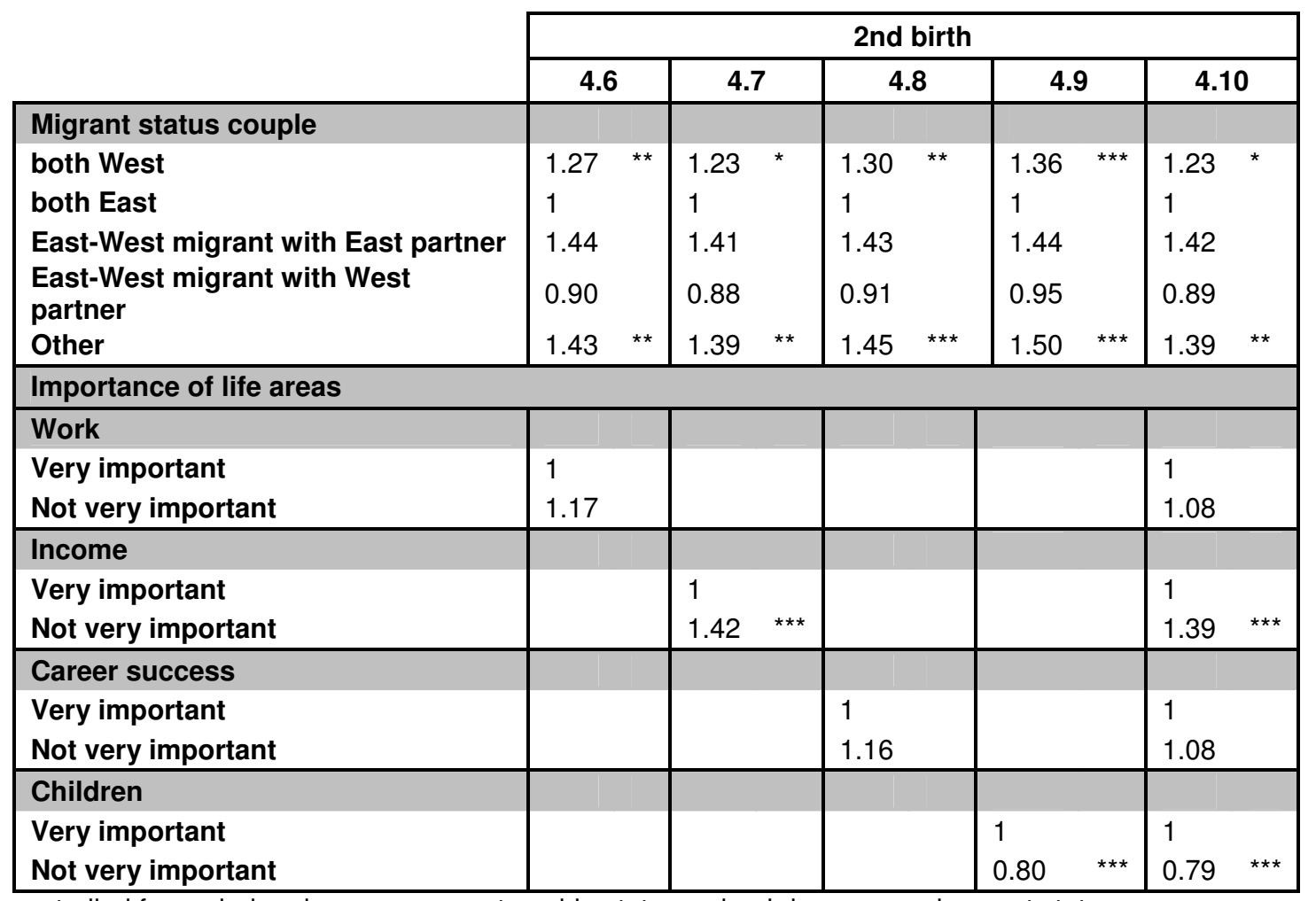

controlled for period and age group, partnership status, school degree, employment status, employment status of partner, religious denomination

${ }^{* * *} p \leq 0.01 ;{ }^{* \star} 0.01<p \leq 0.05 ;{ }^{*} 0.05<p \leq 0.1 ; 11340$ episodes with 890 events

(GSOEP 2009, own estimations) 


\section{Appendix A}

\section{Characteristics of East to West German migrants in the GSOEP sample}

With the GSOEP data used for the fertility analysis, we are able to observe a portion of migrants from eastern to western Germany directly before and after the move, because they enter the panel while they are still residing in the East. We restrict the sample to 16- to 45 -year-olds because this is the age group relevant to the fertility analysis. For men and women residing in eastern Germany, we apply a logistic regression conditional on a move to western Germany in the following year. We find that women are 48 per cent more likely to realise a move from eastern to western Germany. As is typical for migration, moves are concentrated among young people under the age of 30 . People with low levels of commitment are more likely to migrate. This applies to singles or persons in a non-cohabiting relationship, without children and not currently enrolled in education. For childless men, migration risks are positively affected if they are not religiously affiliated; while for women, denomination is not associated with migration. Those who hold a high school degree, and have thus earned the right to attend university, are significantly more likely to move to a western state. Corresponding to migration patterns discussed in 3.2, migration is shown to have been most prevalent in the periods 1990-1994 and 20002004. Not shown in the analysis - though using the same variables on orientation as those used in the fertility analysis and described in Part 4 - was our finding that migrants do not significantly differ from non-mobiles in their work or family orientations directly before the move. Migrants are not more work- or career-oriented than the non-mobiles, although employment-related reasons are - independent of gender - cited by them as the most important factor in the decision to migrate. Moves 
between states within the eastern or western regions are, in contrast, not as employment-related, and are more often motivated by family reasons.

Table A1: Binary logistic regression on migration from eastern Germany to western Germany $(0=$ no move $1=$ move $)$

\begin{tabular}{|c|c|c|c|c|c|c|c|c|}
\hline & \multicolumn{8}{|c|}{ Migration from East to West Germany } \\
\hline & \multicolumn{2}{|l|}{ all } & \multicolumn{2}{|c|}{ childless } & \multicolumn{2}{|c|}{$\begin{array}{c}\text { childless } \\
\text { men }\end{array}$} & \multicolumn{2}{|c|}{$\begin{array}{c}\text { childless } \\
\text { women }\end{array}$} \\
\hline $\begin{array}{l}\text { Men } \\
\text { Women }\end{array}$ & $\begin{array}{l}1 \\
1.48\end{array}$ & $* * *$ & $\begin{array}{l}1 \\
1.50\end{array}$ & & & & & \\
\hline \multicolumn{9}{|l|}{ Age } \\
\hline $\begin{array}{l}16-20 \\
20-24 \\
25-29 \\
30-34 \\
40-45\end{array}$ & $\begin{array}{l}0.89 \\
1 \\
0.80 \\
0.38 \\
0.36\end{array}$ & $\begin{array}{l}* \star * \\
* * *\end{array}$ & $\begin{array}{l}0.98 \\
1 \\
0.71 \\
0.38 \\
0.29\end{array}$ & $\begin{array}{l}* * \\
\star \star * \\
* \star *\end{array}$ & $\begin{array}{l}0.84 \\
1 \\
0.79 \\
0.44 \\
0.31\end{array}$ & *** & $\begin{array}{l}1.06 \\
1 \\
0.58 \\
0.14 \\
0.17\end{array}$ & $\begin{array}{l}* * \\
* * * \\
* * *\end{array}$ \\
\hline \multicolumn{9}{|l|}{ Partnership status } \\
\hline $\begin{array}{l}\text { Single } \\
\text { LAT } \\
\text { Cohabiting } \\
\text { Married } \\
\end{array}$ & $\begin{array}{l}1 \\
1.78 \\
0.50 \\
0.70 \\
\end{array}$ & $\begin{array}{l}* * * \\
* * * \\
\star *\end{array}$ & $\begin{array}{l}1 \\
1.69 \\
0.61 \\
0.99 \\
\end{array}$ & *** & $\begin{array}{l}1 \\
1.85 \\
0.81 \\
1.14\end{array}$ & $* * *$ & $\begin{array}{l}1 \\
1.47 \\
0.46 \\
0.67\end{array}$ & ** \\
\hline \multicolumn{9}{|l|}{ Parental status } \\
\hline $\begin{array}{l}\text { Childless } \\
\text { Parent }\end{array}$ & $\begin{array}{l}1 \\
0.68\end{array}$ & *** & & & & & & \\
\hline \multicolumn{9}{|l|}{ School degree } \\
\hline $\begin{array}{l}\text { Low } \\
\text { Intermediary } \\
\text { High }\end{array}$ & $\begin{array}{l}0.79 \\
1 \\
1.67\end{array}$ & $* * *$ & $\begin{array}{l}0.81 \\
1 \\
1.79\end{array}$ & $* \star \star$ & $\begin{array}{l}0.72 \\
1 \\
1.79\end{array}$ & $* * *$ & $\begin{array}{l}0.86 \\
1 \\
1.77\end{array}$ & *** \\
\hline \multicolumn{9}{|l|}{ Employment status } \\
\hline $\begin{array}{l}\text { In education } \\
\text { Employed full-time } \\
\text { Employed part-time or } \\
\text { marginally } \\
\text { Unemployed } \\
\text { Inactive }\end{array}$ & $\begin{array}{l}0.77 \\
1 \\
0.55 \\
1.13 \\
1.12\end{array}$ & ** & $\begin{array}{l}0.69 \\
1 \\
0.60 \\
0.97 \\
1.34 \\
\end{array}$ & ** & $\begin{array}{l}0.62 \\
1 \\
1.52 \\
0.87 \\
1.57 \\
\end{array}$ & ** & $\begin{array}{l}0.73 \\
1 \\
0.45 \\
1.13 \\
1.28\end{array}$ & \\
\hline \multicolumn{9}{|l|}{ Religious denomination } \\
\hline $\begin{array}{l}\text { No denomination } \\
\text { Protestant } \\
\text { Catholic } \\
\text { Other denomination }\end{array}$ & $\begin{array}{l}1 \\
0.63 \\
0.62 \\
1.16\end{array}$ & *** & $\begin{array}{l}1 \\
0.63 \\
0.69 \\
1.55\end{array}$ & $* * *$ & $\begin{array}{l}1 \\
0.53 \\
0.23 \\
1.79\end{array}$ & $* * *$ & $\begin{array}{l}1 \\
0.71 \\
1.13 \\
1.25\end{array}$ & \\
\hline \multicolumn{9}{|l|}{ Period } \\
\hline $\begin{array}{l}1990-1994 \\
1995-1999 \\
2000-2004 \\
2005-2008\end{array}$ & $\begin{array}{l}1 \\
0.53 \\
0.80 \\
0.51\end{array}$ & $\begin{array}{l}* \star * \\
\star \\
\star \star *\end{array}$ & $\begin{array}{l}1 \\
0.61 \\
0.97 \\
0.67\end{array}$ & $* * *$ & $\begin{array}{l}1 \\
0.67 \\
0.89 \\
0.53\end{array}$ & * & $\begin{array}{l}1 \\
0.59 \\
1.14 \\
0.87\end{array}$ & $* *$ \\
\hline \multicolumn{9}{|l|}{ Sample size } \\
\hline $\begin{array}{l}\text { Persons } \\
\text { Events }\end{array}$ & $\begin{array}{l}6,437 \\
499\end{array}$ & & $\begin{array}{l}3,848 \\
355\end{array}$ & & $\begin{array}{l}2,283 \\
170\end{array}$ & & $\begin{array}{l}1,565 \\
185\end{array}$ & \\
\hline
\end{tabular}

(all covariates $=\mathrm{t}-1$ )

${ }^{* * *} p \leq 0.01 ;{ }^{* *} 0.01<p \leq 0.05 ;{ }^{*} 0.05<p \leq 0.1$

(GSOEP 2009, own estimations) 


\section{Appendix B}

Table A2: Overview of the sample

\begin{tabular}{|c|c|c|c|c|c|c|c|c|c|c|c|}
\hline & \multirow[t]{4}{*}{ Total } & \multicolumn{10}{|c|}{ 1st birth } \\
\hline & & \multicolumn{8}{|c|}{ Individual } & \multirow{2}{*}{\multicolumn{2}{|c|}{$\begin{array}{c}\text { with Partner } \\
\text { Total }\end{array}$}} \\
\hline & & \multicolumn{2}{|c|}{ Total } & \multicolumn{2}{|c|}{ West } & \multicolumn{2}{|c|}{ East } & \multicolumn{2}{|c|}{$\begin{array}{l}\text { East-West } \\
\text { migrants }\end{array}$} & & \\
\hline & & Total & Event & Total & Event & Total & Event & Total & Event & Total & Event \\
\hline \multicolumn{12}{|l|}{ Migrant status } \\
\hline West & $65 \%$ & $70 \%$ & $66 \%$ & & & & & & & & \\
\hline East & $30 \%$ & $24 \%$ & $27 \%$ & & & & & & & & \\
\hline East-West migrants & $6 \%$ & $6 \%$ & $7 \%$ & & & & & & & & \\
\hline \multicolumn{12}{|l|}{ Migrant status couple } \\
\hline No information* & & & & & & & & & & $10 \%$ & $9 \%$ \\
\hline both West & & & & & & & & & & $57 \%$ & $55 \%$ \\
\hline both East & & & & & & & & & & $17 \%$ & $19 \%$ \\
\hline $\begin{array}{l}\text { East-West migrant with } \\
\text { East partner }\end{array}$ & & & & & & & & & & $3 \%$ & $3 \%$ \\
\hline $\begin{array}{l}\text { East-West migrant with } \\
\text { West partner }\end{array}$ & & & & & & & & & & $3 \%$ & $3 \%$ \\
\hline Other & & & & & & & & & & $10 \%$ & $10 \%$ \\
\hline \multicolumn{12}{|l|}{ Partnership status } \\
\hline Single & $20 \%$ & $37 \%$ & $11 \%$ & $36 \%$ & $9 \%$ & $42 \%$ & $16 \%$ & $27 \%$ & $6 \%$ & -- & -- \\
\hline Living apart together & $12 \%$ & $26 \%$ & $17 \%$ & $25 \%$ & $14 \%$ & $29 \%$ & $27 \%$ & $25 \%$ & $12 \%$ & -- & -- \\
\hline Cohabiting & $14 \%$ & $20 \%$ & $33 \%$ & $20 \%$ & $31 \%$ & $18 \%$ & $37 \%$ & $32 \%$ & $45 \%$ & $53 \%$ & $46 \%$ \\
\hline Married & $53 \%$ & $17 \%$ & $39 \%$ & $19 \%$ & $47 \%$ & $12 \%$ & $20 \%$ & $15 \%$ & $37 \%$ & $47 \%$ & $54 \%$ \\
\hline \multicolumn{12}{|l|}{ School degree } \\
\hline No information* & $3 \%$ & $4 \%$ & $3 \%$ & $4 \%$ & $3 \%$ & $4 \%$ & $2 \%$ & $5 \%$ & $5 \%$ & $3 \%$ & $3 \%$ \\
\hline Low & $26 \%$ & $26 \%$ & $18 \%$ & $29 \%$ & $23 \%$ & $23 \%$ & $7 \%$ & $16 \%$ & $15 \%$ & $18 \%$ & $14 \%$ \\
\hline Intermediary & $46 \%$ & $37 \%$ & $46 \%$ & $33 \%$ & $40 \%$ & $47 \%$ & $61 \%$ & $45 \%$ & $47 \%$ & $45 \%$ & $47 \%$ \\
\hline High & $26 \%$ & $33 \%$ & $33 \%$ & $35 \%$ & $34 \%$ & $26 \%$ & $29 \%$ & $34 \%$ & $34 \%$ & $35 \%$ & $36 \%$ \\
\hline \multicolumn{12}{|l|}{ Employment status } \\
\hline In education & $15 \%$ & $36 \%$ & $14 \%$ & $33 \%$ & $8 \%$ & $46 \%$ & $24 \%$ & $34 \%$ & $24 \%$ & $9 \%$ & $7 \%$ \\
\hline Employed full-time & $37 \%$ & $49 \%$ & $70 \%$ & $53 \%$ & $76 \%$ & $38 \%$ & $58 \%$ & $52 \%$ & $65 \%$ & $71 \%$ & $78 \%$ \\
\hline $\begin{array}{l}\text { Employed part-time or } \\
\text { marginal }\end{array}$ & $23 \%$ & $6 \%$ & $8 \%$ & $7 \%$ & $8 \%$ & $5 \%$ & $8 \%$ & $8 \%$ & $2 \%$ & $12 \%$ & $9 \%$ \\
\hline Unemployed & $8 \%$ & $5 \%$ & $6 \%$ & $4 \%$ & $4 \%$ & $8 \%$ & $9 \%$ & $4 \%$ & $8 \%$ & $5 \%$ & $5 \%$ \\
\hline Inactive & $17 \%$ & $4 \%$ & $2 \%$ & $4 \%$ & $3 \%$ & $4 \%$ & $1 \%$ & $3 \%$ & $0 \%$ & $3 \%$ & $2 \%$ \\
\hline \multicolumn{12}{|l|}{$\begin{array}{l}\text { Employment status of } \\
\text { partner }\end{array}$} \\
\hline No information* & & & & & & & & & & $10 \%$ & $9 \%$ \\
\hline In education & & & & & & & & & & $6 \%$ & $5 \%$ \\
\hline Employed full-time & & & & & & & & & & $76 \%$ & $79 \%$ \\
\hline $\begin{array}{l}\text { Employed part-time or } \\
\text { marginal }\end{array}$ & & & & & & & & & & $1 \%$ & $1 \%$ \\
\hline Unemployed & & & & & & & & & & $4 \%$ & $5 \%$ \\
\hline Inactive & & & & & & & & & & $2 \%$ & $1 \%$ \\
\hline Total Episodes & 78,380 & 26,695 & 1,218 & 18,620 & 804 & 6,527 & 328 & 1,548 & 86 & 9,755 & 876 \\
\hline (Persons) & $(10,320)$ & $(4,910)$ & $(1,218)$ & $(3,342)$ & $(804)$ & $(1,347)$ & $(328)$ & (367) & (86) & $(2,465)$ & $(876)$ \\
\hline
\end{tabular}

${ }^{*}$ not shown 


\begin{tabular}{|c|c|c|c|c|c|c|c|c|c|c|c|}
\hline & \multirow[t]{4}{*}{ Total } & \multicolumn{10}{|c|}{ 1st birth } \\
\hline & & \multicolumn{8}{|c|}{ Individual } & \multirow{2}{*}{\multicolumn{2}{|c|}{$\begin{array}{c}\text { with Partner } \\
\text { Total }\end{array}$}} \\
\hline & & \multicolumn{2}{|c|}{ Total } & \multicolumn{2}{|c|}{ West } & \multicolumn{2}{|c|}{ East } & \multicolumn{2}{|c|}{$\begin{array}{l}\text { East-West } \\
\text { migrants }\end{array}$} & & \\
\hline & & Total & Event & Total & Event & Total & Event & Total & Event & Total & Event \\
\hline \multicolumn{12}{|l|}{ Age group } \\
\hline $16-20$ & $10 \%$ & $26 \%$ & $9 \%$ & $22 \%$ & $6 \%$ & $37 \%$ & $16 \%$ & $23 \%$ & $14 \%$ & $3 \%$ & $3 \%$ \\
\hline 20-24 & $14 \%$ & $28 \%$ & $29 \%$ & $25 \%$ & $23 \%$ & $32 \%$ & $42 \%$ & $36 \%$ & $42 \%$ & $23 \%$ & $27 \%$ \\
\hline $25-29$ & $15 \%$ & $19 \%$ & $38 \%$ & $20 \%$ & $40 \%$ & $16 \%$ & $31 \%$ & $23 \%$ & $37 \%$ & $28 \%$ & $43 \%$ \\
\hline $30-34$ & $17 \%$ & $11 \%$ & $19 \%$ & $13 \%$ & $25 \%$ & $6 \%$ & $9 \%$ & $9 \%$ & $6 \%$ & $18 \%$ & $22 \%$ \\
\hline $35-45$ & $43 \%$ & $16 \%$ & $5 \%$ & $19 \%$ & $6 \%$ & $9 \%$ & $2 \%$ & $9 \%$ & $1 \%$ & $28 \%$ & $5 \%$ \\
\hline \multicolumn{12}{|l|}{ Period } \\
\hline 1990-1994 & $21 \%$ & $20 \%$ & $24 \%$ & $20 \%$ & $28 \%$ & $22 \%$ & $18 \%$ & $7 \%$ & $12 \%$ & $22 \%$ & $24 \%$ \\
\hline 1995-1999 & $20 \%$ & $21 \%$ & $25 \%$ & $20 \%$ & $24 \%$ & $23 \%$ & $23 \%$ & $23 \%$ & $37 \%$ & $22 \%$ & $25 \%$ \\
\hline 2000-2004 & $33 \%$ & $35 \%$ & $33 \%$ & $35 \%$ & $31 \%$ & $34 \%$ & $38 \%$ & $38 \%$ & $30 \%$ & $33 \%$ & $33 \%$ \\
\hline 2005-2009 & $27 \%$ & $25 \%$ & $18 \%$ & $25 \%$ & $17 \%$ & $21 \%$ & $22 \%$ & $32 \%$ & $21 \%$ & $23 \%$ & $19 \%$ \\
\hline \multicolumn{12}{|c|}{ Religious denomination } \\
\hline No information* & $3 \%$ & $3 \%$ & $2 \%$ & $3 \%$ & $2 \%$ & $2 \%$ & $2 \%$ & $3 \%$ & $5 \%$ & $1 \%$ & $1 \%$ \\
\hline No denomination & $32 \%$ & $30 \%$ & $29 \%$ & $13 \%$ & $9 \%$ & $71 \%$ & $72 \%$ & $62 \%$ & $53 \%$ & $32 \%$ & $27 \%$ \\
\hline Protestant & $34 \%$ & $35 \%$ & $36 \%$ & $41 \%$ & $42 \%$ & $21 \%$ & $20 \%$ & $26 \%$ & $33 \%$ & $35 \%$ & $37 \%$ \\
\hline Catholic & $28 \%$ & $30 \%$ & $31 \%$ & $41 \%$ & $44 \%$ & $4 \%$ & $6 \%$ & $7 \%$ & $8 \%$ & $29 \%$ & $32 \%$ \\
\hline Other denomination & $2 \%$ & $2 \%$ & $2 \%$ & $3 \%$ & $3 \%$ & $1 \%$ & $0 \%$ & $1 \%$ & $1 \%$ & $2 \%$ & $2 \%$ \\
\hline \multicolumn{12}{|c|}{ Importance of life areas } \\
\hline \multicolumn{12}{|c|}{ Work } \\
\hline No information* & $45 \%$ & $54 \%$ & $46 \%$ & $59 \%$ & $51 \%$ & $41 \%$ & $37 \%$ & $40 \%$ & $27 \%$ & $47 \%$ & $46 \%$ \\
\hline Very important & $22 \%$ & $20 \%$ & $24 \%$ & $16 \%$ & $20 \%$ & $29 \%$ & $30 \%$ & $28 \%$ & $38 \%$ & $24 \%$ & $24 \%$ \\
\hline Not very important & $33 \%$ & $27 \%$ & $31 \%$ & $25 \%$ & $29 \%$ & $30 \%$ & $33 \%$ & $32 \%$ & $35 \%$ & $29 \%$ & $29 \%$ \\
\hline \multicolumn{12}{|l|}{ Income } \\
\hline No information* & $45 \%$ & $53 \%$ & $45 \%$ & $59 \%$ & $51 \%$ & $41 \%$ & $37 \%$ & $40 \%$ & $27 \%$ & $47 \%$ & $46 \%$ \\
\hline Very important & $27 \%$ & $19 \%$ & $23 \%$ & $14 \%$ & $17 \%$ & $32 \%$ & $35 \%$ & $26 \%$ & $35 \%$ & $23 \%$ & $22 \%$ \\
\hline Not very important & $28 \%$ & $27 \%$ & $31 \%$ & $27 \%$ & $32 \%$ & $27 \%$ & $27 \%$ & $34 \%$ & $38 \%$ & $30 \%$ & $32 \%$ \\
\hline \multicolumn{12}{|l|}{ Career Success } \\
\hline No information* & $22 \%$ & $27 \%$ & $25 \%$ & $31 \%$ & $28 \%$ & $21 \%$ & $19 \%$ & $17 \%$ & $16 \%$ & $23 \%$ & $25 \%$ \\
\hline Very important & $20 \%$ & $25 \%$ & $23 \%$ & $21 \%$ & $19 \%$ & $34 \%$ & $31 \%$ & $31 \%$ & $29 \%$ & $23 \%$ & $19 \%$ \\
\hline Not very important & $59 \%$ & $48 \%$ & $53 \%$ & $49 \%$ & $53 \%$ & $46 \%$ & $51 \%$ & $52 \%$ & $55 \%$ & $54 \%$ & $55 \%$ \\
\hline \multicolumn{12}{|l|}{ Family } \\
\hline No information* & $44 \%$ & $53 \%$ & $45 \%$ & $59 \%$ & $51 \%$ & $40 \%$ & $37 \%$ & $39 \%$ & $27 \%$ & $47 \%$ & $46 \%$ \\
\hline Very important & $47 \%$ & $34 \%$ & $44 \%$ & $29 \%$ & $38 \%$ & $47 \%$ & $54 \%$ & $45 \%$ & $59 \%$ & $43 \%$ & $46 \%$ \\
\hline Not very important & $8 \%$ & $13 \%$ & $11 \%$ & $13 \%$ & $11 \%$ & $13 \%$ & $9 \%$ & $17 \%$ & $14 \%$ & $10 \%$ & $7 \%$ \\
\hline \multicolumn{12}{|l|}{ Children } \\
\hline No information* & $27 \%$ & $35 \%$ & $31 \%$ & $32 \%$ & $28 \%$ & $42 \%$ & $37 \%$ & $37 \%$ & $42 \%$ & $29 \%$ & $32 \%$ \\
\hline Very important & $38 \%$ & $13 \%$ & $25 \%$ & $13 \%$ & $28 \%$ & $15 \%$ & $21 \%$ & $13 \%$ & $22 \%$ & $15 \%$ & $28 \%$ \\
\hline Not very important & $34 \%$ & $52 \%$ & $43 \%$ & $55 \%$ & $45 \%$ & $43 \%$ & $42 \%$ & $50 \%$ & $36 \%$ & $55 \%$ & $41 \%$ \\
\hline \multicolumn{12}{|l|}{ Partnership } \\
\hline No information* & $27 \%$ & $35 \%$ & $32 \%$ & $32 \%$ & $28 \%$ & $42 \%$ & $38 \%$ & $36 \%$ & $41 \%$ & $29 \%$ & $32 \%$ \\
\hline Very important & $56 \%$ & $45 \%$ & $57 \%$ & $47 \%$ & $62 \%$ & $39 \%$ & $48 \%$ & $46 \%$ & $49 \%$ & $60 \%$ & $62 \%$ \\
\hline Not very important & $17 \%$ & $20 \%$ & $11 \%$ & $21 \%$ & $10 \%$ & $20 \%$ & $15 \%$ & $18 \%$ & $10 \%$ & $11 \%$ & $7 \%$ \\
\hline Total Episodes & 78,380 & 26,695 & 1,218 & 18,620 & 804 & 6,527 & 328 & 1,548 & 86 & 9,755 & 876 \\
\hline (Persons) & $(10,320)$ & $(4,910)$ & $(1,218)$ & $(3,342)$ & $(804)$ & $(1,347)$ & (328) & (367) & (86) & $(2,465)$ & (876) \\
\hline
\end{tabular}

* not shown 


\begin{tabular}{|c|c|c|c|c|c|c|c|c|c|c|c|}
\hline & \multirow[t]{4}{*}{ Total } & \multicolumn{10}{|c|}{ 2nd birth } \\
\hline & & \multicolumn{8}{|c|}{ Individual } & \multirow{2}{*}{\multicolumn{2}{|c|}{$\begin{array}{c}\text { with Partner } \\
\text { Total }\end{array}$}} \\
\hline & & \multicolumn{2}{|c|}{ Total } & \multicolumn{2}{|c|}{ West } & \multicolumn{2}{|c|}{ East } & \multicolumn{2}{|c|}{$\begin{array}{l}\text { East-West } \\
\text { migrants }\end{array}$} & & \\
\hline & & Total & Event & Total & Event & Total & Event & Total & Event & Total & Event \\
\hline Migrant status & & & & & & & & & & & \\
\hline $\begin{array}{l}\text { West } \\
\text { East } \\
\text { East-West migrants }\end{array}$ & $\begin{array}{c}65 \% \\
30 \% \\
6 \%\end{array}$ & $\begin{array}{c}58 \% \\
35 \% \\
6 \%\end{array}$ & $\begin{array}{c}73 \% \\
22 \% \\
6 \%\end{array}$ & & & & & & & & \\
\hline Migrant status couple & & & & & & & & & & & \\
\hline $\begin{array}{l}\text { No information* } \\
\text { both West } \\
\text { both East } \\
\text { East-West migrant with } \\
\text { East partner } \\
\text { East-West migrant with } \\
\text { West partner } \\
\text { Other }\end{array}$ & & & & & & & & & & \begin{tabular}{c|}
$7 \%$ \\
$48 \%$ \\
$33 \%$ \\
$4 \%$ \\
$2 \%$ \\
$7 \%$
\end{tabular} & \begin{tabular}{r|}
$6 \%$ \\
$59 \%$ \\
$19 \%$ \\
$3 \%$ \\
$2 \%$ \\
$11 \%$
\end{tabular} \\
\hline Partnership status & & & & & & & & & & & \\
\hline $\begin{array}{l}\text { Single } \\
\text { Living apart together } \\
\text { Cohabiting } \\
\text { Married }\end{array}$ & $\begin{array}{l}20 \% \\
12 \% \\
14 \% \\
53 \%\end{array}$ & $\begin{array}{c}12 \% \\
7 \% \\
16 \% \\
66 \%\end{array}$ & $\begin{array}{c}4 \% \\
4 \% \\
15 \% \\
77 \% \\
\end{array}$ & $\begin{array}{c}12 \% \\
7 \% \\
11 \% \\
70 \%\end{array}$ & \begin{tabular}{r|}
$4 \%$ \\
$3 \%$ \\
$11 \%$ \\
$83 \%$
\end{tabular} & $\begin{array}{c}12 \% \\
7 \% \\
23 \% \\
58 \%\end{array}$ & $\begin{array}{c}5 \% \\
10 \% \\
29 \% \\
56 \%\end{array}$ & $\begin{array}{c}10 \% \\
6 \% \\
17 \% \\
68 \% \\
\end{array}$ & $\begin{array}{c}4 \% \\
0 \% \\
14 \% \\
82 \% \\
\end{array}$ & $\begin{array}{c}-- \\
-- \\
19 \% \\
81 \%\end{array}$ & $\begin{array}{c}-- \\
-- \\
16 \% \\
84 \%\end{array}$ \\
\hline School degree & & & & & & & & & & & \\
\hline $\begin{array}{l}\text { No information* } \\
\text { Low } \\
\text { Intermediary } \\
\text { High }\end{array}$ & $\begin{array}{l}3 \% \\
26 \% \\
46 \% \\
26 \% \\
\end{array}$ & $\begin{array}{l}2 \% \\
25 \% \\
52 \% \\
21 \% \\
\end{array}$ & $\begin{array}{l}2 \% \\
20 \% \\
48 \% \\
30 \% \\
\end{array}$ & $\begin{array}{c}2 \% \\
38 \% \\
38 \% \\
22 \% \\
\end{array}$ & $\begin{array}{c}3 \% \\
25 \% \\
41 \% \\
31 \% \\
\end{array}$ & $\begin{array}{c}1 \% \\
7 \% \\
73 \% \\
20 \% \\
\end{array}$ & \begin{tabular}{c|}
$0 \%$ \\
$5 \%$ \\
$70 \%$ \\
$25 \%$ \\
\end{tabular} & \begin{tabular}{c|}
$2 \%$ \\
$11 \%$ \\
$65 \%$ \\
$22 \%$ \\
\end{tabular} & $\begin{array}{c}2 \% \\
16 \% \\
54 \% \\
29 \% \\
\end{array}$ & $\begin{array}{c}2 \% \\
24 \% \\
53 \% \\
22 \% \\
\end{array}$ & $\begin{array}{l}2 \% \\
19 \% \\
48 \% \\
31 \% \\
\end{array}$ \\
\hline Employment status & & & & & & & & & & & \\
\hline $\begin{array}{l}\text { In education } \\
\text { Employed full-time }\end{array}$ & $\begin{array}{l}15 \% \\
37 \%\end{array}$ & $\begin{array}{c}3 \% \\
35 \%\end{array}$ & $\begin{array}{c}5 \% \\
13 \%\end{array}$ & $\begin{array}{c}2 \% \\
25 \%\end{array}$ & $\begin{array}{l}4 \% \\
9 \%\end{array}$ & $\begin{array}{r}4 \% \\
52 \%\end{array}$ & $\begin{array}{c}7 \% \\
27 \%\end{array}$ & $\begin{array}{r}4 \% \\
37 \%\end{array}$ & $\begin{array}{c}4 \% \\
11 \%\end{array}$ & $\begin{array}{c}2 \% \\
34 \%\end{array}$ & $\begin{array}{r}4 \% \\
12 \%\end{array}$ \\
\hline $\begin{array}{l}\text { Employed part-time or } \\
\text { marginal }\end{array}$ & $23 \%$ & $30 \%$ & $29 \%$ & $38 \%$ & $32 \%$ & $17 \%$ & $20 \%$ & $33 \%$ & $36 \%$ & $32 \%$ & $30 \%$ \\
\hline $\begin{array}{l}\text { Unemployed } \\
\text { Inactive }\end{array}$ & $\begin{array}{c}8 \% \\
17 \%\end{array}$ & $\begin{array}{l}10 \% \\
22 \%\end{array}$ & $\begin{array}{c}9 \% \\
43 \%\end{array}$ & $\begin{array}{c}7 \% \\
29 \%\end{array}$ & $\begin{array}{c}6 \% \\
49 \%\end{array}$ & $\begin{array}{l}16 \% \\
11 \%\end{array}$ & $\begin{array}{l}21 \% \\
25 \%\end{array}$ & $\begin{array}{l}8 \% \\
19 \%\end{array}$ & $\begin{array}{c}7 \% \\
43 \%\end{array}$ & $\begin{array}{c}8 \% \\
24 \%\end{array}$ & $\begin{array}{l}8 \% \\
46 \%\end{array}$ \\
\hline $\begin{array}{l}\text { Employment status of } \\
\text { partner }\end{array}$ & & & & & & & & & & & \\
\hline $\begin{array}{l}\text { No information* } \\
\text { In education } \\
\text { Employed full-time } \\
\text { Employed part-time or } \\
\text { marginal } \\
\text { Unemployed } \\
\text { Inactive } \\
\text { Not very important }\end{array}$ & $17 \%$ & $15 \%$ & $8 \%$ & $15 \%$ & $8 \%$ & $15 \%$ & $10 \%$ & $12 \%$ & $9 \%$ & \begin{tabular}{|c|}
$7 \%$ \\
$2 \%$ \\
$84 \%$ \\
$1 \%$ \\
$5 \%$ \\
$1 \%$ \\
$11 \%$
\end{tabular} & \begin{tabular}{r|}
$6 \%$ \\
$3 \%$ \\
$83 \%$ \\
$2 \%$ \\
$5 \%$ \\
$1 \%$ \\
$7 \%$ \\
\end{tabular} \\
\hline $\begin{array}{l}\text { Total Episodes } \\
\text { (Persons) }\end{array}$ & $\begin{array}{l}78,380 \\
(10,320)\end{array}$ & $\begin{array}{l}15,469 \\
(2,976)\end{array}$ & $\begin{array}{c}968 \\
(968)\end{array}$ & $\begin{array}{c}9,046 \\
(1,871)\end{array}$ & $\begin{array}{c}702 \\
(702)\end{array}$ & $\begin{array}{l}5,490 \\
(946)\end{array}$ & $\begin{array}{c}210 \\
(210)\end{array}$ & \begin{tabular}{|c|}
933 \\
$(203)$ \\
\end{tabular} & $\begin{array}{l}56 \\
(56)\end{array}$ & $\begin{array}{l}12,580 \\
(2,680)\end{array}$ & $\begin{array}{c}890 \\
(890)\end{array}$ \\
\hline
\end{tabular}

* not shown 


\begin{tabular}{|c|c|c|c|c|c|c|c|c|c|c|c|}
\hline & \multirow[t]{4}{*}{ Total } & \multicolumn{10}{|c|}{ 2nd birth } \\
\hline & & \multicolumn{8}{|c|}{ Individual } & \multirow{2}{*}{\multicolumn{2}{|c|}{$\begin{array}{c}\text { with Partner } \\
\text { Total }\end{array}$}} \\
\hline & & \multicolumn{2}{|c|}{ Total } & \multicolumn{2}{|c|}{ West } & \multicolumn{2}{|c|}{ East } & \multicolumn{2}{|c|}{$\begin{array}{l}\text { East-West } \\
\text { migrants }\end{array}$} & & \\
\hline & & Total & Event & Total & Event & Total & Event & Total & Event & Total & Event \\
\hline \multicolumn{12}{|l|}{ Age group } \\
\hline $16-20$ & $10 \%$ & $1 \%$ & $2 \%$ & $1 \%$ & $2 \%$ & $2 \%$ & $4 \%$ & $2 \%$ & $2 \%$ & $1 \%$ & $2 \%$ \\
\hline 20-24 & $14 \%$ & $9 \%$ & $16 \%$ & $7 \%$ & $12 \%$ & $11 \%$ & $20 \%$ & $13 \%$ & $41 \%$ & $8 \%$ & $16 \%$ \\
\hline $25-29$ & $15 \%$ & $20 \%$ & $43 \%$ & $19 \%$ & $41 \%$ & $22 \%$ & $50 \%$ & $21 \%$ & $38 \%$ & $21 \%$ & $43 \%$ \\
\hline $30-34$ & $17 \%$ & $23 \%$ & $30 \%$ & $24 \%$ & $33 \%$ & $22 \%$ & $22 \%$ & $25 \%$ & $16 \%$ & $24 \%$ & $30 \%$ \\
\hline $35-45$ & $43 \%$ & $46 \%$ & $10 \%$ & $49 \%$ & $12 \%$ & $44 \%$ & $3 \%$ & $40 \%$ & $4 \%$ & $46 \%$ & $10 \%$ \\
\hline \multicolumn{12}{|l|}{ Period } \\
\hline 1990-1994 & $21 \%$ & $24 \%$ & $24 \%$ & $23 \%$ & $26 \%$ & $28 \%$ & $21 \%$ & $9 \%$ & $5 \%$ & $25 \%$ & $25 \%$ \\
\hline 1995-1999 & $20 \%$ & $22 \%$ & $26 \%$ & $22 \%$ & $27 \%$ & $22 \%$ & $23 \%$ & $27 \%$ & $36 \%$ & $23 \%$ & $27 \%$ \\
\hline 2000-2004 & $33 \%$ & $32 \%$ & $32 \%$ & $34 \%$ & $32 \%$ & $29 \%$ & $32 \%$ & $37 \%$ & $30 \%$ & $32 \%$ & $31 \%$ \\
\hline 2005-2009 & $27 \%$ & $22 \%$ & $17 \%$ & $22 \%$ & $15 \%$ & $21 \%$ & $23 \%$ & $27 \%$ & $29 \%$ & $21 \%$ & $18 \%$ \\
\hline \multicolumn{12}{|c|}{ Religious denomination } \\
\hline No information* & $3 \%$ & $1 \%$ & $0 \%$ & $1 \%$ & $0 \%$ & $1 \%$ & $0 \%$ & $2 \%$ & $0 \%$ & $1 \%$ & $0 \%$ \\
\hline No denomination & $32 \%$ & $39 \%$ & $23 \%$ & $13 \%$ & $7 \%$ & $78 \%$ & $69 \%$ & $64 \%$ & $54 \%$ & $39 \%$ & $22 \%$ \\
\hline Protestant & $34 \%$ & $32 \%$ & $38 \%$ & $41 \%$ & $42 \%$ & $19 \%$ & $23 \%$ & $28 \%$ & $34 \%$ & $32 \%$ & $38 \%$ \\
\hline Catholic & $28 \%$ & $26 \%$ & $36 \%$ & $41 \%$ & $47 \%$ & $3 \%$ & $7 \%$ & $6 \%$ & $9 \%$ & $26 \%$ & $37 \%$ \\
\hline Other denomination & $2 \%$ & $2 \%$ & $3 \%$ & $3 \%$ & $3 \%$ & $0 \%$ & $0 \%$ & $0 \%$ & $4 \%$ & $2 \%$ & $2 \%$ \\
\hline \multicolumn{12}{|c|}{ Importance of life areas } \\
\hline \multicolumn{12}{|l|}{ Work } \\
\hline No information* & $45 \%$ & $37 \%$ & $44 \%$ & $47 \%$ & $50 \%$ & $22 \%$ & $29 \%$ & $23 \%$ & $32 \%$ & $37 \%$ & $45 \%$ \\
\hline Very important & $22 \%$ & $28 \%$ & $18 \%$ & $18 \%$ & $14 \%$ & $42 \%$ & $28 \%$ & $39 \%$ & $27 \%$ & $27 \%$ & $18 \%$ \\
\hline Not very important & $33 \%$ & $35 \%$ & $38 \%$ & $35 \%$ & $36 \%$ & $36 \%$ & $44 \%$ & $38 \%$ & $41 \%$ & $36 \%$ & $38 \%$ \\
\hline \multicolumn{12}{|l|}{ Income } \\
\hline No information* & $45 \%$ & $37 \%$ & $44 \%$ & $47 \%$ & $49 \%$ & $22 \%$ & $29 \%$ & $23 \%$ & $32 \%$ & $37 \%$ & $44 \%$ \\
\hline Very important & $27 \%$ & $34 \%$ & $23 \%$ & $23 \%$ & $18 \%$ & $51 \%$ & $37 \%$ & $43 \%$ & $32 \%$ & $33 \%$ & $22 \%$ \\
\hline Not very important & $28 \%$ & $29 \%$ & $33 \%$ & $30 \%$ & $33 \%$ & $27 \%$ & $35 \%$ & $34 \%$ & $36 \%$ & $30 \%$ & $34 \%$ \\
\hline \multicolumn{12}{|l|}{ Career Success } \\
\hline No information* & $22 \%$ & $19 \%$ & $24 \%$ & $25 \%$ & $29 \%$ & $11 \%$ & $10 \%$ & $12 \%$ & $14 \%$ & $19 \%$ & $25 \%$ \\
\hline Very important & $20 \%$ & $19 \%$ & $14 \%$ & $13 \%$ & $11 \%$ & $28 \%$ & $24 \%$ & $29 \%$ & $18 \%$ & $18 \%$ & $13 \%$ \\
\hline Not very important & $59 \%$ & $62 \%$ & $61 \%$ & $63 \%$ & $60 \%$ & $61 \%$ & $65 \%$ & $60 \%$ & $68 \%$ & $62 \%$ & $62 \%$ \\
\hline \multicolumn{12}{|l|}{ Family } \\
\hline No information* & $44 \%$ & $37 \%$ & $44 \%$ & $47 \%$ & $49 \%$ & $22 \%$ & $29 \%$ & $23 \%$ & $32 \%$ & $37 \%$ & $44 \%$ \\
\hline Very important & $47 \%$ & $56 \%$ & $50 \%$ & $46 \%$ & $44 \%$ & $71 \%$ & $68 \%$ & $68 \%$ & $57 \%$ & $57 \%$ & $50 \%$ \\
\hline Not very important & $8 \%$ & $7 \%$ & $6 \%$ & $7 \%$ & $6 \%$ & $7 \%$ & $3 \%$ & $9 \%$ & $11 \%$ & $6 \%$ & $6 \%$ \\
\hline \multicolumn{12}{|l|}{ Children } \\
\hline No information* & $27 \%$ & $24 \%$ & $26 \%$ & $21 \%$ & $25 \%$ & $28 \%$ & $28 \%$ & $21 \%$ & $30 \%$ & $24 \%$ & $26 \%$ \\
\hline Very important & $38 \%$ & $47 \%$ & $52 \%$ & $47 \%$ & $52 \%$ & $46 \%$ & $50 \%$ & $51 \%$ & $50 \%$ & $49 \%$ & $53 \%$ \\
\hline Not very important & $34 \%$ & $29 \%$ & $23 \%$ & $32 \%$ & $23 \%$ & $26 \%$ & $22 \%$ & $28 \%$ & $20 \%$ & $27 \%$ & $21 \%$ \\
\hline \multicolumn{12}{|l|}{ Partnership } \\
\hline No information* & $27 \%$ & $24 \%$ & $26 \%$ & $21 \%$ & $25 \%$ & $28 \%$ & $29 \%$ & $21 \%$ & $30 \%$ & $24 \%$ & $26 \%$ \\
\hline Very important & $56 \%$ & $61 \%$ & $66 \%$ & $63 \%$ & $67 \%$ & $56 \%$ & $62 \%$ & $67 \%$ & $61 \%$ & $65 \%$ & $67 \%$ \\
\hline Not very important & $17 \%$ & $15 \%$ & $8 \%$ & $15 \%$ & $8 \%$ & $15 \%$ & $10 \%$ & $12 \%$ & $9 \%$ & $11 \%$ & $7 \%$ \\
\hline $\begin{array}{l}\text { Total Episodes } \\
\text { (Persons) }\end{array}$ & \begin{tabular}{|c|}
78,380 \\
$(10,320)$
\end{tabular} & $\begin{array}{l}15,469 \\
(2,976)\end{array}$ & $\begin{array}{c}968 \\
(968)\end{array}$ & \begin{tabular}{|c|}
9,046 \\
$(1,871)$
\end{tabular} & $\begin{array}{c}702 \\
(702)\end{array}$ & $\begin{array}{l}5,490 \\
(946)\end{array}$ & $\begin{array}{c}210 \\
(210)\end{array}$ & $\begin{array}{c}933 \\
(203)\end{array}$ & $\begin{array}{c}56 \\
(56)\end{array}$ & $\begin{array}{l}12,580 \\
(2,680)\end{array}$ & $\begin{array}{c}890 \\
(890)\end{array}$ \\
\hline
\end{tabular}

* not shown 